\title{
norden
}

\section{Regulatory Safety Assessment of Nanomaterials}

Are we facing the same challenges as the regulation of endocrine disrupting chemicals?

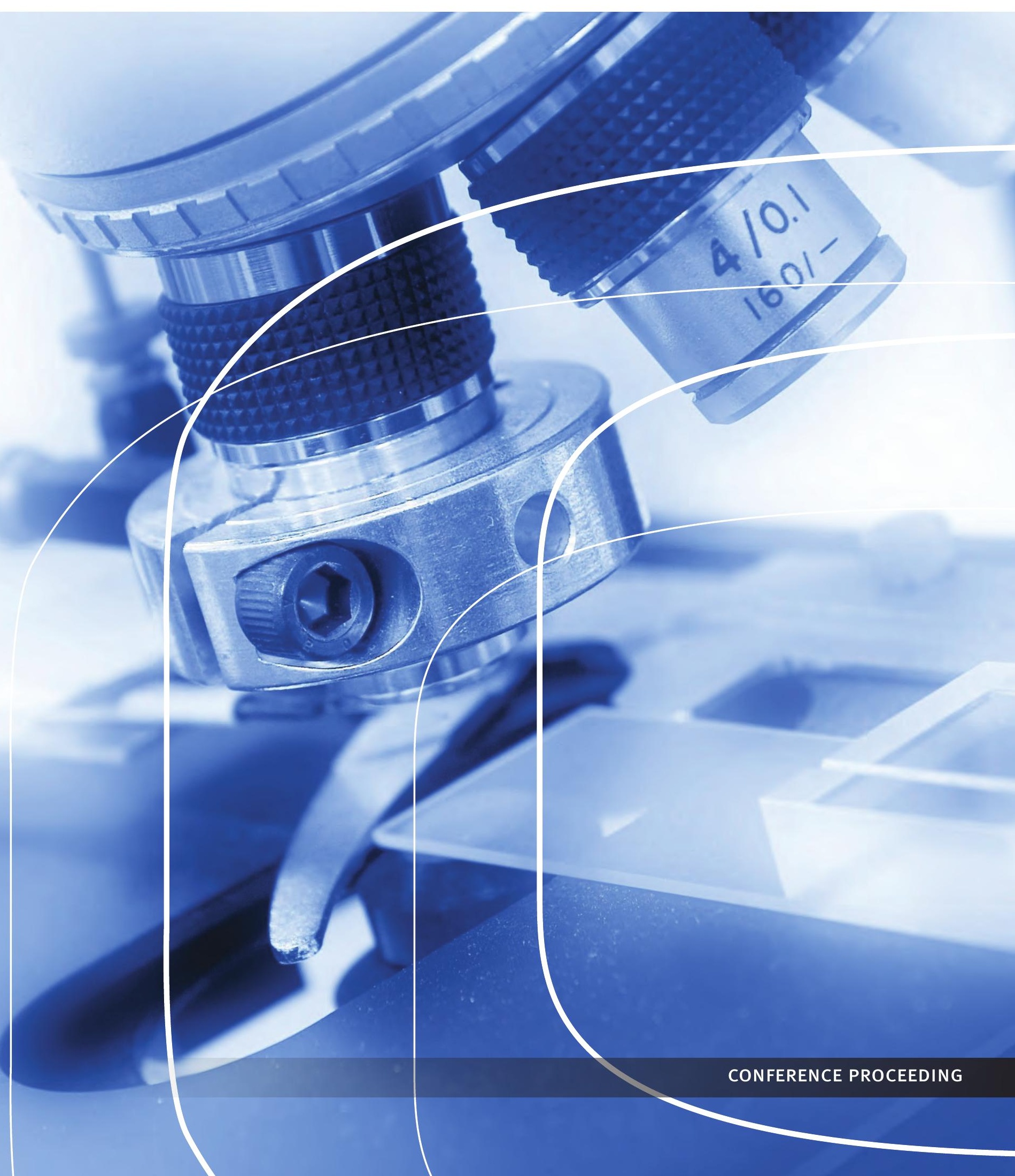



4 norden 



\section{Regulatory Safety Assessment of Nanomaterials}

Are we facing the same challenges as the regulation of endocrine disrupting chemicals?

Jukka Ahtiainen \& Elina Väänänen,

Finnish Safety and Chemicals Agency (Tukes) 
Regulatory Safety Assessment of Nanomaterials

Are we facing the same challenges as the regulation of endocrine disrupting chemicals? Jukka Ahtiainen \& Elina Väänänen, Finnish Safety and Chemicals Agency (Tukes)

TemaNord 2012:515

ISBN 978-92-893-2343-7

http://dx.doi.org/10.6027/TN2012-515

(c) Nordic Council of Ministers 2012

Cover photo: Image Select

This publication has been published with financial support by the Nordic Council of Ministers. However, the contents of this publication do not necessarily reflect the views, policies or recommendations of the Nordic Council of Ministers.

www.norden.org/en/publications

Nordic co-operation

Nordic co-operation is one of the world's most extensive forms of regional collaboration, involving Denmark, Finland, Iceland, Norway, Sweden, and the Faroe Islands, Greenland, and Åland.

Nordic co-operation has firm traditions in politics, the economy, and culture. It plays an important role in European and international collaboration, and aims at creating a strong Nordic community in a strong Europe.

Nordic co-operation seeks to safeguard Nordic and regional interests and principles in the global community. Common Nordic values help the region solidify its position as one of the world's most innovative and competitive.

Nordic Council of Ministers

Ved Stranden 18

DK-1061 Copenhagen K

Phone (+45) 33960200

www.norden.org 


\section{Content}

Preface.

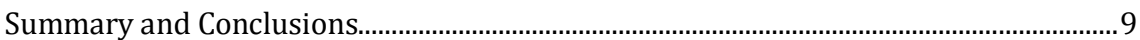

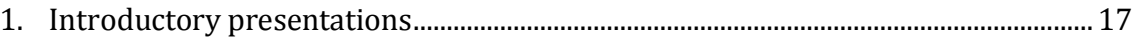

1.1 Technical challenges and policy issues (Jukka Ahtiainen, Tukes, FI) ..........17

1.2 Networks as a tool for regulatory actions: The Danish Endocrine

Network (Henrik Tyle, Danish EPA, DK)..

1.3 The OECD Conceptual Framework on Endocrine Disrupters

(Petteri Talasniemi, Tukes, FI)

1.4 Revised OECD Conceptual Framework for Endocrine Disrupters and the draft OECD GD on testing and assessment of chemicals for ED

(Henrik Tyle, Danish EPA, DK)

1.5 NM definition and substance identification (Emma Vikstad, Kemi, SE)........... 23

1.6 Implementing REACH on NMs: EU guidance on NM safety assessment (Poul Bo Larsen, Danish EPA, DK)

2. Break-out groups on the regulatory framework and the links between

EDC and NM issues.

2.1 Decisions and guidance - proceed or wait for new scientific

information?.

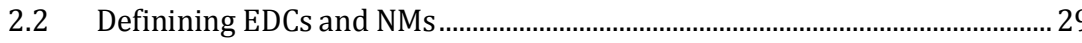

2.3 REACH - regulating EDCs and NMs............................................................... 31

2.4 Registration of NMs ...................................................................................... 33

2.5 Adequacy of existing legislation to regulate confirmed EDCs....................... 34

2.6 A practical example on NMs REACH registration of Nano Fibril Cellulose.............................................................................................................. 34

3. Presentations on test guidelines and their applicability to assess NMs .................... 35

3.1 What TG tools we have, and which TGs and GDs have to be developed for NM testing (Peter Kearns, OECD EHS/ENV) ..

3.2 REACH and Information Requirements for safety assessment (Jukka Ahtiainen, Tukes, FI) ............................................................................. 36

3.3 OECD Sponsorship Programme and NM testing (Sjur Andersen, KLIF, NO) .................................................................................................... 37

3.4 Nordic nanoAg contribution to the Sponsorship Programme (Janneck Scott-Fordsmand, DMU, DK) 38

3.5 Environmental fate studies on NMs (Erik Joner, Bioforsk, NO and Deborah Oughton, Norwegian University of Life Sciences, NO) .................... 39

3.6 Detection of NMs in the environment and verification of exposure (Geert Cornelis, University of Gothenburg, SE) ............................................... 40

3.7 Inhalation of nanoparticles and health effects (Marit Låg, Norwegian Institute of Public Health, NO) ................................................... 41

3.8 Update on genotoxicity of NMs (Julia Catalán, FIOH, FI) ................................ 42

3.9 In vitro studies in NM testing - Experience from NanoTEST (Lise Fjellsbø, NILU, NO)

3.10 Aquatic effects and fate of nanomaterials in the Nordic environment (Jussi Kukkonen, University of Eastern Finland, FI) 43 
4. Break-out groups on test guidelines and their applicability to assess NMs.

4.1 Existing test guidelines and new guidance for the hazard and safety assessment of NMs.

4.2 Technical guidance for specific areas of testing ............................................ 47

4.3 Guidance based on NM groups ............................................................................ 47

$4.4 \quad$ Nanospecific endpoints................................................................................. 48

4.5 Test Guideline Modification and the Mutual Acceptance of Data ................ 49

5. Presentations on the regulatory possibilities for EDCs and NMs............................. 51

5.1 Outcome of the three Nordic workshops on EDCs held in Denmark in 2010 (Sofie Christiansen, DTU, Pia Juul Nielsen and Rikke Holmberg, Danish EPA, DK).

5.2 Regulation of combined effects - status of the EU work (Rikke Holmberg, Danish EPA, DK) 52

5.3 Registration of $\mathrm{ZnO}$ in REACH - is it sufficient for safety evaluation of nano ZnO? (Katarzyna Malkiewicz, Kemi, SE) ............................................. 52

6. Presentations on regulating NMs.................................................................................. 57

6.1 Summary on the TG applicability and TG/GD needs (Poul Bo Larsen, Danish EPA, DK and Jukka Ahtiainen, Tukes, FI)............................... 57

6.2 Current regulatory views in the EU (Henrik Laursen, DG ENV, EC) ............ 58

6.3 Registrations of NMs (Marita Luotamo, ECHA)............................................. 59

6.4 Towards harmonization of national databases for NMs on the market

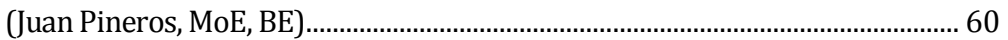

6.5 French reporting scheme for Nanomaterials (Clarisse Durand, Ministry of Ecology, Sustainable Development, Transports and Housing, FR) ................ 61

6.6 Example(s) on NM safety assessment and RMM (Nicole Palmen, RIVM, NL)........

6.7 Nanotoxicology: Science at the interphases, Estonian perspective (Kaja Kasemets, National Institute of Chemical Physics and Biophysics, EE)............ 63

7. Discussion and views on Nordic possibilities in regulating NMs ................................65

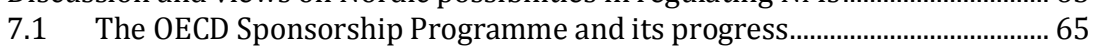

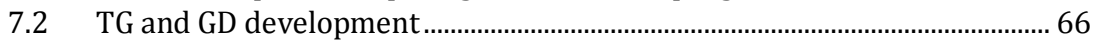

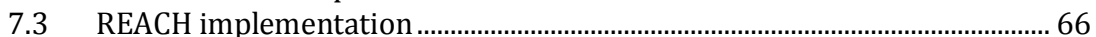

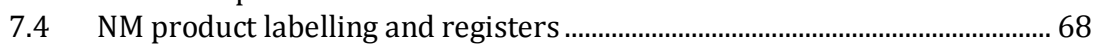

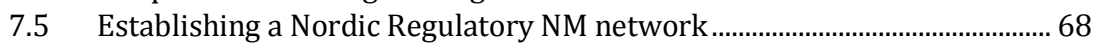

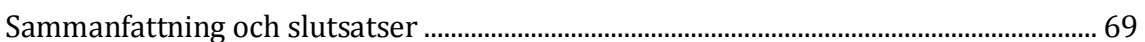

Abbreviations ................................................................................................................ 77

Appendix A: Programme .............................................................................................. 79

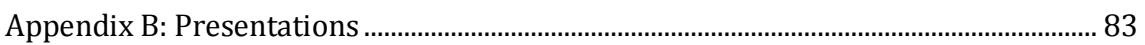

Appendix C: List of Participants................................................................................... 85 


\section{Preface}

\section{Opening Speech}

"Ladies and gentlemen,

I would like to wish you a warm welcome to Finland and to Hanasaari Congress Centre. I am very pleased to have this opportunity to address this meeting. Nordic cooperation is much appreciated here in Finland, and I know that the cooperation on chemical issues has contributed a lot to our work towards better management of hazardous substances on the EU level and internationally.

The Nordic governmental cooperation within the field of chemicals began already in 1976 with the establishment of the Nordic Product Control Group. In comparison, the Nordic Council of Ministers was established in 1971. At that time, only Denmark was a member of the European Community. This meant that most of the discussions in the Nordic Product Control Group focused on issues brought to and discussed in the context of the European Community chemicals agenda. Many criteria documents for harmonized classification of chemical substances were prepared within the Control Group and, then, were taken to the EU by our Danish colleagues. Ten years after the group was formed, the name of the group was changed to the Nordic Chemicals Group.

One of the most successful Nordic cooperation efforts on chemicals, which I would like to mention, was carried out in 1987-1992 on the strengthening of global discussions concerning ozone depleting substances.

In 1995 Finland and Sweden joined the European Community. This triggered the need for an overall review of the aims and organizational structure of the Nordic governmental cooperation within the framework of the Nordic Council of Ministers. The cooperation thus became more focused and, according to political aims, should be carried out within areas where there is an added Nordic value (nordiskt nytta), that is, where there is a need to cooperate because it strengthens the corresponding national, European or global work.

The cooperation within the Nordic Chemicals Group has always been seen as close and successful. It has been commended during all reviews, 
especially because of its ability to change focus according to the needs of the work. I am supporting this assessment, based on my own experiences of serving for 15 years as the Finnish representative on the Nordic committee for environmental issues.

The Chemicals Group has worked in areas where the Nordic countries share equal aims concerning health and environmental protection. Many thanks to the committed people working on these projects.

The present Finnish Government has also expressed support of the Nordic work on chemical issues in general and on related issues under discussion in this very seminar. This is what the Government Programme says:

\footnotetext{
"Implementation of the (2006 launched) National Chemicals Programme will continue. The adequacy of the current measures in achieving the international goals regarding the minimisation of the environmental and health risks of chemicals by 2020 will be assessed and the programme revised accordingly. The need for additional measures required by new and upcoming subjects such as nano materials, materials affecting hormonal activity, and the interaction of chemicals will be evaluated."
}

By arranging this seminar, the Nordic Nano Steering group, the Nordic Risk Assessment Group, Nord-UTTE on test guideline work and the Nordic Council of Ministers are giving their valuable input also into the implementation of our Government Programme. But what is even more important, as a part of Nordic efforts, is that this meeting is a step along the way to developing criteria for EU- and international-level safety assessments and risk management practices for nanos and EDCs.

I would like to encourage all of you to actively take part in exchanging information and in discussions, not only during the sessions but also informally in hallway chats, to take full advantage of the well-prepared agenda and the top experts who are present here as speakers or participants. I hope you will have a successful meeting here in Hanasaari during the upcoming three days."

Pekka Jalkanen

Ministry of the Environment Finland and

Chair of the Nordic Committee of Senior Officials

for Environmental Affairs

Nordic Council of Ministers 


\section{Summary and Conclusions}

The Nordic NanoNet Workshop and EDC discussion was organised as part of the 2011 Finnish chairmanship of the Nordic Council of Ministers (NMR). The conference, organised by the Finnish Safety and Chemicals Agency (Tukes), took place between the $11^{\text {th }}$ and $13^{\text {th }}$ of October 2011 at Hanasaari Congress Centre in Espoo, Finland. While the meeting focused on the safety assessment and management of nanomaterials (NMs), a parallel one-day session was dedicated to Endocrine Disrupting Chemicals (EDC) Criteria. The organisers are thankful to the Nordic Council of Ministers for providing the resources for the meeting.

The broad themes of the conference were:

- The regulatory frameworks and the links between NMs and EDCs

- Applicability of test guidelines and risk assessment tools for nanomaterials

- Regulatory possibilities for EDCs and NMs

- Regulation of NMs

- Developing EDC Criteria

- Future Nordic regulatory cooperation

\section{The Regulatory Framework and the Links between EDC and NM Issues}

Introductory presentations on the regulatory framework and the links between EDC and NM issues were launched by Jukka Ahtiainen (Tukes, FI), who introduced some of the central themes and objectives of the meeting. Speaking on behalf of Pia Juul Nielsen, Henrik Tyle (Danish EPA, DK) used the Danish Endocrine Network as an example of a network for regulatory action that has improved understanding between regulators and scientists. Petteri Talasniemi (Tukes, FI) introduced the revised OECD Conceptual Framework (CF) and pointed out that guidance limitations stem from two sources: either there is insufficient experience of the use of the assay in question or the assay does not offer significant advantages over existing studies. In his presentation on the revised OECD CF and the draft OECD Guidance Document (GD) for EDCs, Henrik Tyle advocated a case-by-case approach to chemicals assessment that takes into account all available information. 
Emma Vikstad (Kemi, SE) highlighted the imperative for a single nanomaterial definition to encompass all nanorelevant EU legislation. Poul Bo Larsen (Danish EPA, DK) pointed out that much work is needed to incorporate nanomaterials into REACH and suggested that perhaps a separate, more flexible regulation for nanomaterials in parallel with REACH could be an appropriate solution.

Break-out groups on the regulatory frameworks and the links between EDC and NM issues concluded the first day of the conference. The conclusions are presented below.

\section{Proceed with decisions or wait for more scientific information?}

The view that we should not wait for more scientific information before going forward with decisions and guidance prevailed. In the case of nano, high uncertainty and lack of clarity on what further information is needed strengthens the case for swift regulatory action. For EDCs, the basis for regulation and the state of the knowledge is better-defined.

\section{Defining nanomaterials}

All groups saw an imminent need for a nanomaterials definition to allow regulatory action to take place. A practical approach to the definition was favoured in the current situation of persistent uncertainty. It was however concluded that the scientific basis should be incorporated into this practical approach. Groups also agreed on the need of an EDC definition and criteria covering all hormonal modalities.

\section{REACH - regulating EDCs and NMs}

Even though there was no consensus opinion on how the REACH regulation could ensure the safety of NMs, participants agreed that further measures to ensure safety under the regulation are needed. Potential methods for ensuring that NMs are addressed separately from the bulk substance include amending the regulation or providing new or revised annexes or adequate ECHA guidance for registration. It was seen that for the identification of EDCs under REACH, a new Annex on EDC criteria, alike to the annex for PBT criteria, was probably necessary.

\section{Registation of NMs}

There was a strong general feeling, that it would be safer to categorically register NMs as new substances with nano-adapted data requirements. Nevertheless, other adequate means, such as better ECHA guidance on registration, were also supported. 


\section{Adequacy of existing legislation to regulate EDCs}

The existing regulatory tools were considered generally adequate to regulate confirmed EDCs. However, the combined effects of EDCs from different sources were perceived difficult to address sufficiently by existing legislation.

\section{Applicability of Test Guidelines and Risk Assessment Tools for Nanomaterials}

The second day of the Nordic NanoNet Workshop focused on the applicability of test guidelines (TGs) and risk assessment (RA) tools for nanomaterials. Peter Kearns' (OECD, EHS/ENV) presentation gave an overview of OECD work on NMs and elaborated on the relationship of the principles of Good Laboratory Practice and the Mutual Acceptance of Data in relation to test guideline and guidance document development. Jukka Ahtiainen outlined possibilities for further development of testing practice: the creation of a conceptual framework for NM testing and assessment in the style of the EDC Conceptual Framework is an option. Sjur Andersen (KLIF, NO) presented on the OECD sponsorship programme and introduced the scope of testing and the relevant sponsors involved. Janneck Scott-Fordsmand (DMU, DK) elaborated on the Nordic nanosilver contributions to the sponsorship programme and discussed some of its testing challenges, sparking a lively discussion.

Erik Joner (Bioforsk, NO) and Deborah Oughton (Norwegian University of Life Sciences, NO) jointly presented on environmental fate studies on NMs: testing in relevant soil conditions including ageing was concluded to be important as were the possibilities for using neutron action as a method to detect metallic NMs. Geert Cornelis (University of Gothenburg, SE) then addressed the detection of NMs in the environment and the issues relating to the verification of exposure - field-flow fractionation (FFF) coupled to inductively coupled plasma-mass spectrometry (ICP-MS) and single particle ICP-MS (SP-ICP-MS) were proposed for sensitive analysis of engineered nanoparticles in complex environmental media.

In her presentation on the inhalation of nanoparticles, Marit Låg (Norwegian Institute of Public Health, NO) concluded that engineered nanoparticles have a potential to elucidate health effects, the toxicity of which will depend on the exposure to these particles. Julia Catalán (FI$\mathrm{OH}, \mathrm{FI}$ ) gave an update on the genotoxicity testing of NMs and the challenges faced - for example, it is often unknown how much of the nanomaterial is taken up by cells and whether differences in intracellular 
pathways could explain differences in genotoxicity. Lise Fjellsbø (NILU, NO) drew on experiences from the NanoTEST project studying the uptake and transport of nanoparticels through biological barriers in discussing in vitro studies in NM testing. The final presentation of the day was delivered by Jussi Kukkonen (University of Eastern Finland, FI) who spoke about the aquatic effects and fate of nanomaterials in the Nordic Environment.

The discussion on applicability continued in break-out group discussions, the results of which are presented below.

\section{Existing test guidelines and new guidance}

Groups agreed that while development of further guidelines is necessary, existing guidelines are an adept starting point for the safety and hazard assessment of nanomaterials. The existence of technical and conceptual challenges to the existing guidelines was acknowledged. The need for flexibility in guidance was emphasised by all groups.

\section{Guidance for specific areas of testing and guidance based on NM groups}

Different guidance for different areas of testing was seen necessary. Grouping nanomaterials remains practically difficult. Nevertheless, it was seen that if grouping could overcome these practical hurdles, it would be a desirable basis for guidance.

\section{Regulatory possibilities for EDCs and NMS}

The third day of the conference began with a session on the regulatory possibilities for EDCs and NMs. Sofie Christiansen, Pia Juul Nielsen and Rikke Holmberg (Danish EPA, DK) presented the outcomes of three Nordic EDC workshops on criteria, combined effects and soft regulatory measures held in Copenhagen in the autumn of 2010. Rikke Holmberg also delivered an update on the status of EU regulatory work on EDCs, combined effects and NMs. Katarzyna Malkiewicz (Kemi, SE) ended the session with her presentation on the registration of zinc oxide in REACH by recommending the request of further nanospecific data in connection to REACH substance evaluation. A separate session on developing EDC criteria, parallel to a session on regulating nanomaterials was then run by representatives of the Danish EPA. 


\section{Regulating NMS}

In opening the session on regulating nanomaterials, Poul Bo Larsen (Danish EPA, DK) and Jukka Ahtiainen (Tukes, FI) emphasised the emergence of new nano-specific endpoints and the need to develop guidance and new test guidelines in the area of physico-chemical properties.

Henrik Laursen (DG ENV, EC) provided an overview of key EU actions and views on the regulation of NMs; the ongoing legislative overview aims to establish whether current legislation ensures safety and sustainability as well as competitiveness and innovation. Marita Luotamo (ECHA) discussed NM experiences and future developments under REACH: a caseby-case approach to the registration of nanomaterials was preferred.

Juan Piñeros (MoE, BE) introduced the case for harmonizing national databases for NMs on the market: benefits include enabling data collection and exposure estimations, risk assessment and managent systems and improvement of the legislative framework. Clarisse Durand (Ministry of Ecology, Sustainable Development, Transport and Housing, FR) then went into more detail on the French mandatory reporting scheme initiative, undertaken in cooperation with Belgium and Italy.

Nicole Palmen (RIVM, NL) presented examples of NM safety assessment, particularly from the point of view of occupational exposure to engineered nanoparticles. The final presentation by Kaja Kasemets (NICPB, EE) discussed research on the ecotoxicology of synthetic nanoparticles at the NICPB.

\section{Discussion on Nordic regulatory cooperation on NMS}

A discussion on Nordic cooperation within the EU and OECD frameworks ended the Nordic NanoNet Workshop. The conclusions of this discussion aimed for regulators are presented below.

\section{The OECD Sponsorship Programme and its progress}

There are huge expectations on the OECD testing of 13 nanomaterials for various endpoints. The data from the ongoing explorative phase 1 for possible hazard identification is not yet completely available but we should already commence planning for phase 2, where the data produced should be suitable for risk assessment. The phase 2 testing should be guided by some kind of a testing strategy or Conceptual Framework like for EDCs, developed based on the existing data. 


\section{TG and GD development}

In general, the OECD guidelines are applicable for investigating the health effects, ecotoxicity and environmental fate of nanomaterials with the important proviso that additional consideration needs to be given to the physicochemical characteristics of the material tested. In some cases, there may be a need for further modification to the OECD guidelines. Preparation of samples and dose administration are critical considerations for the tests and therefore guidance has been developed on sample preparation and dosimetry for the safety testing of nanomaterials. The preliminary review of OECD-WPMN is consequently seen as a "living" document, highlighting the feasibility of various approaches and allowing for continuous updates, given the rapid developments in this area.

There was a consensus that very few potential new nanospecific endpoints need to be added to the Test Guidelines or developed as new Test Guidelines. These new nanospecific needs are mainly in the area of physico-chemical characterization. However, some of the endpoints in existing Test Guidelines are more nanorelevant than others. In the area of ecotoxicity most of the existing endpoints are also nanorelevant. In the area of environmental fate testing the detection and characterization of NMs in the environmental media or in tissues is the challenge.

\section{REACH implementation}

The information submitted in the registration dossier for a nanomaterial, as part of the bulk registration or on its own, needs to comply with the information requirements and, if relevant, the CSR requirements for all the registrant's identified uses of the nanomaterial.

There is no one-size-fits-all solution to treating nanomaterials as forms of a bulk substance or a separate substance. Further practice needs to evolve on developing rules on how size should be used as a characterizer and when could it be used as an identifier. The Nordic countries may have differing views on whether NMs should be always registered as substances of their own and considered as new substances. However, if the former were to apply, the data requirements based on tonnages should be reconsidered.

If specific substance identification rules for nanomaterials are developed, they must be consistent with practices for substances in general. Such rules need to maintain a certain degree of flexibility to allow use of the most practical solutions, provided that the information is relevant and complete for all forms of the substance, and that safe use is ensured.

REACH obliges the registrant to ensure that his registration(s) demonstrate(s) that all forms of the substance in his dossier(s) can be used safely. The question of substance identity is not critical in this regard. The 
focus of attention should therefore be on ensuring that the submitted data are applicable or appropriate for the all form(s) covered in a dossier(s) in question and on ensuring that the registrant has provided all relevant information to allow the safe use of the substance by the downstream users and consumers. There are however concerns amongst the Nordic countries whether industry would comply with this properly. Only 3 registrants out of 46 with NM use of the same substance had indicated the nanomaterial use in IUCLID at the first registration in 2010.

Standard information requirements, as described in the Annexes VII $\mathrm{XI}$, apply equally to nanoforms and bulkforms. The registrant has to make sure that in case tests are performed, these must be representative of the form(s) of the registered substance. It was concluded that nano-specific data requirements would need new tonnage triggers and data requirements. This would also translate to the need for a common registration.

ECHA has been invited to further assess the relevant submitted dossiers in a "bottom-up" process to build up more knowledge and experience on substance identification in the registration of nanomaterials. If appropriate, ECHA should use this experience to develop further practical rules in co-operation with the European Commission, Member States and stakeholders. Such a bottom-up process should significantly contribute to a better understanding on how nanomaterials are to be treated within the REACH framework. This could be perhaps supported by Nordic countries as an interim solution. However, the revised ECHA Guidance on registration should make explicit, that the registrants and SIEF are to address and assess all the relevant uses of NMs of that particular substance. This demand should be very visible and clear, probably under the title "What to register".

It was also proposed that if a member state's regulators have doubts that the safety assessment of a NM form is not adequate, these substances (e.g. the case of ZnO; having the nanoform in the market) could be raised into the CORAP (Community Rolling Action Plan for the evaluation of substances) process by a member state.

It was also discussed whether a separate regulation for nanomaterials would be more appropriate, in order not to make changes within REACH. Based on the experiences in the RIP-oNs and the experiences from the OECD sponsorship programme, a future task for Nordic cooperation could be to start work on examining specific triggers for data requirement and a testing strategy for nanomaterials. 


\section{Establishing a Nordic Regulatory NM network}

Strengthening Nordic cooperation in the field of nanosafety was supported. This should bring together research groups and regulators. Regulatory views could thus be better discussed and coordinated. The core of this nano-group should also coordinate NM related work in all NKG groups.

If Nordic countries have reason to doubt the adequacy of NM safety assessment in registration and one of the countries would take this to the CORAP-process for substance evaluation, there should be strong Nordic support and resources for this process.

Starting a TG/GD project in the OECD test guideline programme was discussed as a concrete idea for future regulatory cooperation. The meeting identified two possible fields where there is need for work and Nordic scientific capacity. For ecotoxicology, the development of Guidance Document(s) for soil and sediment toxicity could be such an area. In the human health area, the knowledge on genotoxicity assessment could be clearly identified. One possibility is to get involved with the development of a Comet assay for an OECD TG, and ensure that it would also become applicable for NM testing as well as for general chemicals. 


\title{
1. Introductory presentations
}

\author{
1.1 Technical challenges and policy issues \\ (Jukka Ahtiainen, Tukes, FI)
}

The introductory presentation on technical challenges and policy issues related to EDCs and NMs raised some of the questions central to the themes and goals of the meeting. A main concern was whether we should proceed with decision-making and guidance on NMs and EDCs or alternatively wait for new scientific information before acting. The adequacy of the definitions for EDCs and NMs were addressed at length. Should definitions be strictly scientific or also include practical considerations? Should the EDC definition cover all hormonal modalities, including effects related to immunotoxicology and metabolia? Should we strive for a common NM definition in all EU legislation?

The adequacy of the current regulatory framework was also addressed. The role of REACH in regulating EDCs and NMs was highlighted, especially with reference to potential revisions. Should only guidance for registration and safety assessment be revised and updated? Should new annexes in REACH be created for EDC criteria? Should a revised annex VI identify NMs as their own and separate new substance with size and form included as additional identifiers? Should NMs be generally registered as new substances, separate from the bulk substance or should the registrant be allowed the discretion to determine how to handle them? If a substance can be considered as a confirmed EDC, are regulatory actions in the new Biocide, PPP and REACH regulations sufficient?

A practical NM example on the REACH registration of Nano Fibril Cellulose invited participants to consider three scenarios and their impact on registration. Bearing in mind that bleached pulp is exempted from registration, what should happen if nano fibril cellulose was manufactured mechanically from cellulose pulp? What if it was coated by absorption (e.g. by polyvinyl acrylate)? How about if nano fibril cellulose was chemically modified, would it then fall under the REACH registration?

Test guidelines and their applicability to assess NMs were also discussed from the point of view of existing guidelines and their development. Can the hazard and safety assessment be managed by existing test guidelines by only developing new technical guidance (e.g. OECD Guid- 
ance Documents) applicable for the handling and characterisation of exposures to NMs? Should this technical guidance be developed for various areas of testing (e.g. soil studies, aquatic studies, or inhalation and skin studies)? Should guidance be based on NM groups (e.g. metal, metal oxide NMs)? The existence of new nano-specific or nano-relevant endpoints was raised including the areas of physical-chemical properties, ecotoxicology environmental fate (degradation and accumulation included) and toxicology.

The presentation did not seek to answer these multifaceted questions but instead to set the backdrop for the meeting and invite participants to engage with these questions in the course of the workshop, especially during the break-out group work.

\subsection{Networks as a tool for regulatory actions: The Danish Endocrine Network (Henrik Tyle, Danish EPA, DK)}

Cooperation within the Danish Endocrine network has provided an opportunity for fruitful integration of research and test method development, resulting in important new findings as well as regulatory interventions. The Centre for Endocrine Disrupters has played a key role in this work: it has applied research directed towards preventive work, including regulation.

The network has organised meetings twice a year. Meetings have featured presentations by the authorities on new initiatives and topical debates relating to testing, assessment and regulatory actions on EDs as well as by researchers on new scientific results and general test method issues. Network meetings have resulted in better communication and understanding between regulators and scientists on multiple levels. Scientific results have been better linked to their use in a regulatory context, research has become more targeted in relation to regulatory needs and press communication has been better coordinated between the two groups. The meetings have also fostered communication and understanding between scientists of various disciplines.

\section{General assessment and decision making framework on EDC's}

The general approach for testing, assessment and management of substances with hazardous properties of special concern has been to discriminate between substances that are "confirmed / regarded as", "suspected for" or having "potential for" such properties. Two categories 
distinguish between ED in vivo (confirmed) (1) and suspected ED (in vivo) (2a) or potential ED (in vitro / in silico) (2b).

The Nordic input to the OECD EDTA recommends that in the case of an EDC in vivo and with the presence of risk, risk reduction by restriction of production/ use or authorisation should occur. With a suspected EDC in vivo, preliminary risk assessment could possibly be accompanied by an additional assessment factor. If risk is perceived, soft regulatory intervention should take place and/ or definitive testing and evidence from industry should be required. Industry should thus be incentivised to provide more confirmatory evidence. In the case of a potential EDC in vitro / in silico, prioritisation for further investigations should occur together with provision of supporting evidence and WoE expert judgements.

\section{"Strict" and "Soft" Management}

Management is divided into two categories: "strict" and "soft". Strict management should be resorted to when the level of evidence is high and the severity of the effect is large. Strict management should preferably translate to strong regulation at the EU level, including restrictions and authorisation. Soft management should be applied while considering the level of evidence and the severity and nature of hazard and risk. If suspicion results to be substantiated and the effects is severe, regulatory intervention at the national level should follow. Creating incentives for the generation of confirmatory evidence is of great importance within the realm of soft management.

General principles for soft regulatory intervention presented prescribe avoidance of unnecessary use of the chemical and minimisation of exposure. Furthermore, promotion of the generation of definitive evidence is highlighted. To make these principles operational, communication and advice to the public is encouraged and provision of incentives to industry via development of alternative substances and promotion of voluntary risk reduction agreements is recommended. On the EU level, promotion of regulatory action is needed, especially for the generation of definitive date and advancing regulation based on the precautionary principle. 


\subsection{The OECD Conceptual Framework on Endocrine Disrupters (Petteri Talasniemi, Tukes, FI)}

The OECD Conceptual Framework (CF) is developed to provide a framework for the testing and assessment of endocrine disrupters (EDs). The framework works as a guide to the available assays for information on EDs, including assays developed to test guidelines as well as assays under development for screening and testing EDs. The original conceptual framework agreed in 2002 by OECD Task Force on endocrine disrupters testing and assessment is being superseded in 2011 by an updated version by the OECD EDTA Advisory Group.

The Conceptual Framework is included in Annex 1 of the 'Guidance document on standardised test guideline for evaluating chemicals for endocrine disruption' (under finalization at OECD EDTA AG). The guidance document provides scope for guidance for regulatory authorities to interpret results from assays included in the CF for testing and assessment of EDs.

The Conceptual Framework includes validated or widely-accepted assays (harmonized OECD and national test guidelines) for ED outcomes. Some assays are included in the Conceptual Framework but not in the Guidance document, or at times, only limited guidance exists. These limitations in guidance stem from two sources: either there is insufficient experience of their use (e.g. vertebrate lifecycle assays and in vitro thyroid function assay) or the assays do not offer significant advantages over existing assays (e.g. fish hepatocyte vitallogenin function assay). As the Conceptual Framework is subject to periodic revisions, it evolves as a "living document". Assays included in the Conceptual Framework are defined precisely to facilitate the mutual acceptance of data (MAD).

The revised Conceptual Framework (2011) divides data and assays into five levels, each characterised by the type of information it generates:

- Level 1. Existing data and non-test information

- Level 2. In vitro assays providing data about selected endocrine mechanism(s)/pathway(s)

- Level 3. In vivo assays providing data about selected endocrine mechanism(s)/pathway(s)

- Level 4. In vivo assays providing data on adverse effects on endocrine relevant endpoints

- Level 5. In vivo assays providing more comprehensive data on adverse effects on endocrine relevant endpoints over more extensive parts of the life cycle of the organisms 
It is of note, that the Conceptual Framework is not a testing strategy to be followed linearly from level 1 to 5 , but can provide ideas about where to start testing. The data generated at various levels have a range of differing applications and implications. The Guidance Document is used for interpreting assay results, in line with the weight of evidence approach.

\subsection{Revised OECD Conceptual Framework for Endocrine Disrupters and the draft OECD GD on testing and assessment of chemicals for ED (Henrik Tyle, Danish EPA, DK)}

In introducing the revised OECD Conceptual Framework for Endocrine Disrupters and the draft OECD Guidance on testing and assessment of chemicals for Endocrine Disruptors (ED), the presentation reviewed some of the implications for assessment of High Production Volume Chemicals (HPVCs) for reproductive toxicity including ED.

For both mammalian and non-mammalian toxicology, level 1 of the Conceptual Framework encompasses existing data and non-test information. This includes physical and chemical properties (e.g. MW reactivity, volatility), all available (eco) toxicological data from standardised and non-standardised tests and QSARs, other in silico predictions and ADME model predictions.

Level 2 of the framework comprises of in vitro assays providing data about selected endocrine mechanisms and pathways. Such mechanisms include oestrogen and androgen binding affinity, oestrogen receptor transcriptional activation, androgen or thyroid transcriptional activation, in vitro steroidogenesis and MCF-7 cell proliferation assays.

Level 3 consists of in vivo assays for selected endocrine mechanisms. For mammalian toxicology, the Uterotrophic assay (TG 440) and the Hershberger assay (TG 441) are utilised, whereas for non-mammalian toxicology, an array of assays include Xenopus embryo thyroid signalling assay, Amphibian metamorphosis assay (TG 231), Fish Reproductive Screening Assay (TG 229), Fish Screening Assay (TG 230) and Androgenized female stickleback screen (GD 140).

Level 4 of the Conceptual Framework consists of in vivo assays for non-mammalian toxicology and the adverse effects on endocrine relevant end-points. Tests include Fish Sexual Development Test (TG 234), Fish Reproduction Partial Lifecycle Test, Larval Amphibian Growth \& Development Assay, Avian Reproduction Assay (TG 206), Mollusc Partial Lifecycle Assays and Chironomid Toxicity Test (TG 218-219). 
Level 5 is divisible into in vivo assays for mammalian toxicity and non-mammalian toxicity. This translates to more comprehensive data on the endocrine relevant endpoints over more extensive parts of the life cycle of the organism for the former (e.g. Extended one-generation reproductive Toxicity Study (TG 443), 2-generation assay (TG 416)) and more comprehensive data on adverse effects on endocrine relevant endpoints over more extensive parts of the life cycle of the organism for the latter (e.g. FLCTT (Fish LifeCycle Toxicity Test), Medaka Multigeneration Test (MMGT)).

It was emphasised that the assessment of each chemical should be on a case-by-case basis, taking into account all available information, bearing in mind the function of the framework levels. The frameworks should not be considered as all inclusive at the present time. At levels 2 , 3,4 and 5, assays are included that are either available or provisional, as their validation is still under way.

REACH poses somewhat extensive tonnage triggered standard information requirements on reproductive toxicity. A controversial question however remains in whether the new TG 443, the Extended OneGeneration Reproductive Toxicity Study (EOGRTS) could be required instead of the REACH requirements. There has been extensive discussion on this in the Member State Committee (MSC) but no agreement has been reached. The majority of MSC members do not think it is legally possible to require EOGRTS because REACH specifically refers to "a two generation reproductive toxicity test". The Nordic countries also disagree on the issue: Denmark advocates EOGRTS as a standard information requirement under REACH while Norway, Sweden and Finland only accept the use of EOGRTS under REACH if testing of F2 is triggered in all cases.

A CARACAL EOGRTS group has been established to mediate the disagreement. The group found that the EOGRTS is the most up-to date and comprehensive repro-tox higher-tier test with a generally increased sensitivity (number of analysed animals) and scope (range of new reprotox parameters especially on ED). The group agreed that no scientific triggers relating to intrinsic properties can be identified for triggering F2. The group agreed that DNT and DIT is default and can only be omitted if not scientifically necessary. The group decided to recommend TG 443 to be included in the EU TM Regulation as soon as possible. Some proposed ECHA to recognize TG 443 as appropriate in the meantime and to revise REACH Annexes. Denmark sees these developments as highly urgent and commendable due to the superiority of the EOGRTS test. 


\subsection{NM definition and substance identification (Emma Vikstad, Kemi, SE)}

A definition for nanomaterial is imperative in a regulatory context. At the moment multiple definitions exist, impairing the ability to discuss the issue convincingly. In the Cosmetics Directive nanomaterials are defined as "insoluble or biopersistant", "intentionally manufactured" and to be of " 1 to $100 \mathrm{~nm}$ " of size. The Restriction of Hazardous Substances Directive defines nanomaterials as "substances of very small size", while the Novel Food regulation finds them to have "discrete functional and structural parts" of "100 nm or less" in size.

\section{Towards a harmonised EU definition?}

The Draft Commission Recommendation (article 2) on the definition of the term "nanomaterial" (2010) finds that a nanomaterial is a material that meets at least one of following criteria. Firstly, the material either needs to consist of particles, with one or more external dimensions in the size range from $1 \mathrm{~nm}$ to $100 \mathrm{~nm}$ for more than $1 \%$ of their number size distribution, or secondly, to have internal or surface structures in one or more dimension in the size range between $1 \mathrm{~nm}$ and $100 \mathrm{~nm}$. The additional criterion requires a specific surface area by volume greater than $60 \mathrm{~m} 2 / \mathrm{cm} 3$, excluding materials consisting of particles with a size lower than $1 \mathrm{~nm}$. Public consultation on this recommendation took place in 2010 and will hopefully soon lead to a harmonised EU definition.

\section{Substance identification of nanomaterials under REACH}

A debate on substance identification exists in parallel to that of the definition. CARACAL (Competent Authorities for REACH and CLP regulations) has delegated substance identification of nanomaterials under REACH to its sub-group, CASGnano, consequently creating the expert group RIPoN1 on substance identification. The RIPoN1 project was aiming to be strictly scientific and technical and remain apolitical while taking a bottom-up approach to "evaluate the applicability of the existing guidance" and "if needed, to develop specific advice on how to establish the substance identity of nanomaterials". The RIPoN1 process has been problematic from its premise, divorcing science and politics, onwards; there have also been practical difficulties of differing starting points and views within the group as well as the lack of a definition.

The single most prominent issue has been size as an identifier, acting a triggering point for a new substance under REACH, versus size as a characteriser, not amounting to a new substance under REACH but de- 
termining the substance as a form of an existing substance. Consensus was reached on carbon nano tubes not being graphites, constituting one of the few issues where consensus was achieved. The RIPoN1 Advisory Report published in March 2011 was followed by CARACAL consultation and we are yet to see what action will follow from the Advisory Report both in terms of the definition and substance identification.

\subsection{Implementing REACH on NMs: EU guidance on NM safety assessment (Poul Bo Larsen, Danish EPA, DK)}

The work on implementing REACH on NMs was presented and the outcome of the three RIP-oN projects were discussed.

\section{RIP-oN 1 Substance Identity}

The conclusion from this project was that a policy decision has to be made on whether size, surface area and surface treatment should be considered as characterisers or identifiers for a substance. If size is an identifier then this would require separate registrations for nanomaterials.

\section{RIP-oN 2 Information requirements}

The applicability of the existing test methods was evaluated and the need for further/ additional relevant data for nanomaterials was assessed. Overall very little concrete nanospecific guidance could be proposed for inclusion in the REACH guidance documents. No specific testing strategy for nanomaterials could be suggested. However, further guidance on sample preparation and granulometry were proposed. Altogether the project gives a good overview concerning our present knowledge and how far we can go with recommendation on nanomaterials in relation to the various test end-points.

\section{RIP oN3 Chemical safety assessment}

The RIPon3 on chemical safety assessment aimed to give further advice on the development of exposure scenarios; on operational conditions and risk management/ mitigation measures, and exposure estimation. It also addressed these in relation to hazard and risk characterisation including derivation of DNELs and PNECs. Overall further guidance in relation to risk management measures, operational conditions and personal protective equipment was given. The relevant exposure metrics were recommended such as weight based, number based and surface based 
particle concentration in air. Exposure estimation tools in general were not available for estimation of air-borne exposure levels. The recommendation is to use our general hazard characterisation approach for nanomaterials using DNEL derivation and the existing default values for assessment factors.

Overall much remains to be done in order to implement nanomaterials in REACH, as REACH has not been designed for nanomaterials. For example, the tonnage based triggers for information requirements do not seem to apply for nanomaterials. It may be more appropriate to have a separate and more flexible regulation for nanomaterials in parallel with REACH so that no changes in REACH would be necessary, and a nanospecific testing strategy could be more easily implemented. 



\section{Break-out groups on the regulatory framework and the links between EDC and NM issues}

Four break-out groups discussed pre-given questions relating to the regulatory framework and links between EDC and NM issues. The conclusions from each group are presented below.

\subsection{Decisions and guidance - proceed or wait for new scientific information?}

Should we proceed with decisions and guidance or still wait for new scientific information on NMs and EDCs?

\section{Group A}

- We should not wait for new scientific evidence before acting but proceed with regulation based on the information we have

- A case-by-case treatment seems an unattractive solution: industry requires stability to react and function efficiently

- Even though an array of tests exists for nanomaterials, their applicability and guidance need to be further considered

\section{Group B}

- With regards to regulating EDCs two questions are of relevance: how do EDCs disturb the hormone system and how does it relate to adverse effects? As regulation cannot be based on endocrine action, a relationship is needed between endocrine action and adverse effects. With nanomaterials, it is the fundamental uncertainty that we are circulating around. In the absence of a clear link to be established, the goals of regulation are not straight-forward

- With nanomaterials, we cannot wait for more information as we do not know what we are waiting for. At the moment we are uncertain of 
a multitude of factors, including what is exposure and what is it that we are testing. Instead of waiting, we need to learn by doing and engage in a process of iteration and use experience and consequent better information to improve regulation and practice

\section{Group C}

- At the moment we do not know much about NMs or what questions to ask. Furthermore, the questions asked now may be different in a few years time

- However, we should not only focus on science but also consider the regulatory basis. The basis for regulation and testing is less clear for NMs than for EDCs

- At the moment Carbon Nano Tubes are not classified and as they differ from each other, there is variation of form and effects within the same chemical

- Should chemicals that we do not know about be placed on the market? With asbestos, we only knew about its effects afterwards

- We could turn the question around and state that industry is responsible for the safety of their own products (and this REACH principle applies also NMs); industry should wait for the proof that NMs are safe and address the unknown concerns

- In conclusion, we should not wait to act even if we do not currently have all the answers

\section{Group D}

Nano

- What information are we waiting for? Should we suspect that nanomaterials act differently? Should the regulatory approach be proactive or passive? Are we waiting for the (epidemiological) hazard evidence? The case of nanosilver is illustrative of these dilemmas

- We are waiting for a definition - it is not possible to proceed before a definition is accepted

- There is political pressure to develop decisions and TGD on "nano"

- We may not have seen scientific evidence on nanospecific hazards and therefore there is no proof of the need to develop nanospecific TGD

- We could start with deciding and developing guidance on a case-bycase basis 
EDCs

- We are already engaged in the decision-making process and guidance development, but we need to focus on development and validation of the testing strategy and commonly agreed criteria

\section{Summary}

The view that we should not wait for more scientific information before going forward with decisions and guidance prevailed across groups. In the case of nano, high uncertainty and lack of clarity on what further information is needed strengthened the case for swift regulatory action. For EDCs, the basis for regulation and the state of the knowledge seemed better-defined.

\subsection{Definining EDCs and NMs}

- Do we have an adequate science based definition for EDCs and NMs? Should the definitions be scientific or purely practical?

- Should the EDC definition cover all hormonal modalities (effects related to immunotox and metabolia)? Should we have a single common definition for NMs in all legislation?

\section{Group A}

- The lack of definitions constitutes a major deficiency

- The process of creating a definition was seen to be hampered by industry and the lack of definitions a potential excuse for inaction

- The scientific disagreement that currently prevails would suggest that a potential definition needs to be practical. Nevertheless, definitions should have a scientific basis, especially for the sake of measurability. The practical unit for measurement also needs to be carefully considered

- An EDC definition should cover all hormonal modalities

\section{Group B}

- When choosing between approaches to defining nano, the practical approach is preferred. Better definitions will eventually follow from regulatory action

- Concern was expressed that in the case of nano, we are defining something that you cannot define. Therefore dealing with specific cases, learning by doing and ultimately taking a bottom-up approach to criteria and definition seem correct 
- A definition is imperative; even as a starting point for regulatory action

- The 2010 Commission draft recommendation on nanomaterial definition was a positive development that could be adopted

- Discussion on potency of effects and criteria was discussed. Perhaps, both for NMs and EDCs, you have to regulate those problems which are most obvious: what do we know, what are we most concerned about and start regulating there

\section{Group C}

- The definition should be based on science but should simultaneously be practical for the regulatory context

- Industry is against the $1 \%$ limit (in the draft Commission recommendation) because it claims that then all of their products would contain NMs

- The philosophy is different behind the definitions for EDCs and NMs - for EDCs the focus is on the mechanisms, while for NMs it is the description of material that matters

- The definition for NMs should be general. Different regulations (cosmetics, food etc.) could then have specific amendments to the general definition

- For medicine, the definition is less important than for other products, as it is so extensively tested and strictly regulated

- For EDCs, all hormonal modalities should be covered in the definition

\section{Group D}

Nano

- The Significant New Use Rule (SNUR) in the US EPA was proposed as an example to illustrate how to handle and separate NMs from the bulk substance

- We need a definition that is both science-based and practical

- From the scientific point of view there are criteria for a definition

- From the political point of view there is resistance to use such a definition due to economical and sociological consequences (public opinion)

$E D C s$

- A definition should cover all hormonal modalities. Nevertheless, it needs to be recognized that the consequences of this could be drastic as numerous effects could be considered as EDC effects 


\section{Summary}

All groups saw an imminent need for a nanomaterials definition to allow regulatory action to take place. A practical approach to the definition was favoured in the current situation of persistent uncertainty. The scientific basis should however be incorporated into this practical approach. Break-out groups also agreed on the need of an EDC definition covering all hormonal modalities.

\subsection{REACH - regulating EDCs and NMs}

- Can REACH take care of EDCs and NMs without any revisions?

- Should only guidance for the registration and safety assessment be revised and updated?

- Are new annexes to REACH needed for EDC criteria?

- Should there be a revised annex VI for NM identification as its own substance (size and form as additional identifiers)?

\section{Group A}

- Currently, REACH lacks specific reference to nano, indicating that revision is needed

- Even though REACH claims to cover all forms of chemicals, inventory of data submitted to dossiers shows that very little data on nano has been submitted

- We need to decide whether REACH is the right framework for regulating nanomaterials and consider whether there any alternatives to it

- Can the Nordic group have influence over amending REACH?

- A definition is necessary for the development of any regulation

- There are no specific data requirements for EDCs identification in REACH. Cocktail effects constitute a larger concern

- Perhaps new annexes could be part of the solution. Current work on annexes includes EDC criteria

\section{Group B}

- Nanomaterials are not chemicals in the normal sense and therefore regulation by REACH is complicated. Even though tonnage levels are far too high for nanomaterials, some specific nanomaterials could be regulated by REACH and its scope could then be gradually expanded

- As the Commission seems to prefer making no changes to regulations, changing annexes seems a feasible, lighter mechanism as opposed to major amendments 
- Further problems in adjusting REACH to nanomaterials are numerous. Change in regulation would be difficult due to the EU Parliament and Council; nano discussion is not mature enough to address the standard data requirements of tonnage triggers and whether nanoforms are phase-in substances. Thus problems in relation to substance identity (enzymes, macromolecules, mixtures) abound

- It was also noted that it is most important to ensure adequate safety assessment of all forms and uses of the substance. Whether the NMs are registered as separate substances or together with the bulk form (dossier within dossier), may not be an issue

\section{Group C}

- In REACH the changes could be made via ATPs (amendment to technical progress) to Annexes, as the Commission is unlikely to open up the REACH legal text for changes. Guidance is made by ECHA and is not legally binding

- For NMs, changes in the Annexes I (safety assessment) and VI (information requirements) should occur instead of guidance

- For EDCs, guidance would be a good idea, even though classification should also be discussed. There should first be a new REACH Annex for EDC criteria, similarly to Annex XIII for PBTs. Perhaps after that it could get into the CLP through the GHS (Globally Harmonised System of Classification and Labelling Chemicals)

\section{Group D}

- In the case of nano, REACH will need revisions

- Guidance to the regulation and updated safety assessment are not sufficient measures. There is a need to revise the main text and the Annexes, and perhaps include an additional Annex (e.g. on identification)

- The question with reference to EDCs was not within the group's expertise

\section{Summary}

Even though there was no consensus opinion on how the REACH regulation could ensure the safety of NMs, participants agreed that further measures to ensure safety are needed. Potential methods for ensuring that NMs are addressed separately from the bulk substance include amending the regulation or providing new or revised annexes or adequate ECHA guidance for registration. It was seen that for the identification of EDCs under REACH, a new Annex on EDC criteria, alike to the annex for PBT criteria, was probably necessary. 


\subsection{Registration of NMs}

Should NMs be generally registered as new substances separate from the bulk substance, or should it be left up to the registrant how to handle them?

\section{Group A}

- Sticking to the bulk form may yield more information

\section{Group B}

- Whether NMs in question are phase-in or new substances is relevant to the question

- With reference to whether registration should be left up to the registrant, it seems that industry cannot be held responsible backwards in time

\section{Group C}

- There is a tendency to support separate registrations for the bulk and NMs

- Substance identification has to be extended

- If bulk and NMS were to be registered separately, would the total volume and consequently the information requirements for NMs be reduced? Also, would there be separate registration fees?

- Could this separation of bulk and NMs be done by changing the guidance? This question connects to the previous one: changes in the Annexes I (safety assessment) and VI (information requirements) should occur instead of guidance. Methods of evaluation could however be handled in the guidance

\section{Group D}

- NMs should be registered as separate substances unless specific evidence provided shows the opposite

\section{Summary}

There was a strong general feeling, that it would be safer to always register NMs as new substances with nano-adapted data requirements. Nevertheless, other adequate means, such as better ECHA guidance on registration, were supported. 


\subsection{Adequacy of existing legislation to regulate confirmed EDCs}

If a substance can be considered as confirmed EDC are the regulatory actions in new biocide, PPP and REACH regulation adequate?

\section{Group C}

- The regulations are adequate to some degree: under the Reprotox 1A/B classification, we have the tools to regulate

- However for the combined effects, regulations are not sufficient because chemicals are under a different regulatory framework

- N.B. Groups B and D did not answer the question due to time constraints

\section{Summary}

The existing regulatory tools were generally considered adequate. However, the combined effects of EDCs from different sources were perceived as difficult to tackle.

\subsection{A practical example on NMs REACH registration of Nano Fibril Cellulose}

How would you handle the REACH registration of Nano Fibril Cellulose, as bleached pulp is exempted from registration (annex IV, Cellulose Pulp):

- if it is manufactured from cellulose pulp mechanically

- if it is coated by adsorption e.g. by PVA

- if it is chemically modified?

\section{Group C}

- If it is manufactured from cellulose pulp mechanically, it depends on the level of change

- If it is coated by adsorption (e.g. by PVA), it becomes a borderline case

- If it is chemically modified, it should be taken out from the exemptions

- N.B. Groups A, B and D did not answer the question due to time constraints 


\section{Presentations on test guidelines and their applicability to assess NMs}

\subsection{What TG tools we have, and which TGs and GDs have to be developed for NM testing (Peter Kearns, OECD EHS/ENV)}

\section{Mutual Acceptance of Data and the OECD principles of Good Laboratory Practice}

The principle of Mutual Acceptance of Data (MAD)is defined in the OECD Council Decision on Mutual Acceptance of Data in an Assessment of Chemicals C(81)30(Final) as follows:

\footnotetext{
"Decides that the data generated in the testing of chemicals in an OECD Member country in accordance with OECD Test Guidelines and OECD Principles of Good Laboratory Practice shall be accepted in other Member countries for purposes of assessment and other uses relating to the protection of man and the environment."
}

The OECD principles of Good Laboratory Practice (GLP) enforce a single quality standard for test facilities throughout OECD, applied for testing of all chemical substances. It is linked to a management tool that addresses the responsibility and requirements for a test facility's organisation and personnel, quality assurance programme, physical plant, apparatus, materials and reagents. Principles governing conditions, procedures and performance are also provided. Good laboratory practice in combination with the use of OECD test guidelines leads to Mutual Acceptance of Data.

The benefits of Mutual Acceptance of Data include avoiding duplication of testing by industry: the consequent cost savings amount to as much as 150 million euros a year. In addition, the principle reduces nontariff trade barriers as MAD Council Decisions are open to selected adhered non-members. There are approximately 150 test guidelines with guidance on physical-chemical properties, human toxicity, ecotoxicity, bio-degradation and accumulation and pesticide residue testing. 


\section{OECD Working Party on Nanomaterials}

The OECD Working Party on Nanomaterials was established in September 2006. It aims to promote international co-operation on the human health and environmental safety of manufactured nanomaterials. It also involves the safety testing and risk assessment of manufactured nanomaterials under the OECD Sponsorship Programme. The programme consists of two phases: Phase 1 launched in 2007, tested selected NMs for the selected endpoints, whereas Phase 2, planned to commence in 2011, will consider cross-cutting issues and the need for further tests that are identified in Phase 1. Phase 1 of the Sponsorship Programme is expected to be completed in mid-2012. WPMN achievements include publishing the Preliminary Guidance Notes for Sample Preparation and Dosimetry (GNSPD) and a review for further GD development or updating TGs.

\subsection{REACH and Information Requirements for safety assessment (Jukka Ahtiainen, Tukes, FI)}

\section{New information and endpoints for NMs}

The question of whether new information and endpoints are needed for NMs was raised. In the case of degradation and bioaccumulation, the existing test for detection is deemed sufficient. For physical-chemical properties, new information and endpoints are however necessary. For toxicology and ecotoxicology, many of the existing endpoints seem adequate even though some additional endpoints could be considered.

\section{Applicability of OECD Test Guidelines for NM testing}

With regards to the applicability of the OECD Test Guidelines for NM testing, biological "endpoints" or measurement variables are found relevant and applicable. The number of offspring in reproduction tests, bioaccumulation into tissues and $\mathrm{CO}_{2}$ production in the biodegradation test are examples of applicable biological endpoints. It was noted that dosing of the test material and test media affects both exposure and consequent effects. NM detection and characterisation were seen very important at the start and during the test. It thus follows that relevant dose metrics should be used (mg/L or surface area or particle number) and that terminology has to be clear (e.g. dissolved $\left(\mathrm{Ag}^{+}\right)$or dispersed (Agnanoparticles); agglomerate and aggregate).

Conclusions on the methods for biotic effects and fate were to recommend following the best guidance available. In addition, careful recording of all the details of the process was prescribed to enable retro- 
spective analysis. Finally, detecting and characterising the NM exposure to the best ability at every step of testing was encouraged.

If the measured variables in the existing Test Guidelines are NMrelevant, the use of Test Guidelines needs to be contemplated. Possible developments could include a whole new set of Test Guidelines for NM testing or a suite of Guidance Documents to use the existing TGs. Ensuring the mutual acceptance of data is also of utmost importance while considering such developments. The creation of a conceptual framework for NM testing and assessment, in the style of the EDC Conceptual Framework could be another step to be taken. If measures to develop guidance were to be taken, their position within the REACH regulation needs to be considered. Options for this include having a separate annex, integrating nano-specific guidance to the ECHA registering guidance or alternatively having totally different guidance, separate from REACH.

\subsection{OECD Sponsorship Programme and NM testing (Sjur Andersen, KLIF, NO)}

The OECD WPMN sponsorship programme is currently examining 13 different nanomaterials with regards to their physical-chemical properties, environmental fate, human and environmental properties. The programme has two phases: Phase 1 for information gathering and Phase 2 for acquiring data for risk assessment. Part of the program aims to provide input to another group that addresses potentially necessary changes to the OECD Test Guidelines when testing nanomaterials. The Sponsorship Programme is based on voluntary contributions - at the moment the USA and the EC have the lead. The Nordic countries contribute to the examination of nanosilver and the funding is provided by the Nordic chemicals group. A table of the currently tested materials and the level of contributions is presented below. 
Table 1: Contributions to the OECD Sponsorship Programme

\begin{tabular}{|c|c|c|c|}
\hline \multirow{2}{*}{$\begin{array}{l}\text { OECD set of materi- } \\
\text { als tested }\end{array}$} & \multicolumn{3}{|c|}{ Level of sponsorship } \\
\hline & Lead sponsor(s) & Co-sponsor(s) & Contributor \\
\hline Fullerenes (C60) & Japan, US & & China, Denmark \\
\hline SWCNTS & Japan, US & Korea, BIAC for MWCNT & $\begin{array}{l}\text { Germany, BIAC, Canada, EC, } \\
\text { France, China }\end{array}$ \\
\hline \multicolumn{4}{|l|}{ MWCNTS } \\
\hline Silver nanoparticles & US, Korea & $\begin{array}{l}\text { Germany, Australia, Canada, } \\
\text { Nordic Council of Ministers }\end{array}$ & $\begin{array}{l}\text { EC, France, China, Netherlands, } \\
\text { BIAC }\end{array}$ \\
\hline Iron nanoparticles & China & $\mathrm{BIAC}$ & $\begin{array}{l}\text { US, Canada, Nordic Council of } \\
\text { Ministers }\end{array}$ \\
\hline \multicolumn{4}{|l|}{ Carbon black } \\
\hline Titanium dioxide & $\begin{array}{l}\text { Germany, } \\
\text { France }\end{array}$ & $\begin{array}{l}\text { Austria, Canada, Spain, } \\
\text { BIAC, Korea, US }\end{array}$ & China, Denmark, UK \\
\hline Aluminium oxide & & & Germany, US \\
\hline Cerium oxide & UK/BIAC, US & Netherlands, Australia, Spain & Germany, EC, Switzerland \\
\hline Zinc oxide & BIAC & Australia, Spain, US & Canada, Denmark, Japan \\
\hline Silicon dioxide & EC, France & BIAC (CEFIC), Belgium, Korea & Denmark, Japan \\
\hline \multicolumn{4}{|l|}{ Polystyrene } \\
\hline Dendrimers & & Spain, US Austria, Korea & Spain, US Austria, Korea \\
\hline Nanoclays & BIAC & & US, Denmark, EC \\
\hline Nanogold & South Africa & Korea, US & EC \\
\hline
\end{tabular}

\subsection{Nordic nanoAg contribution to the Sponsorship Programme (Janneck Scott-Fordsmand, DMU, DK)}

The Nordic countries have established a collaborative testing programme to contribute to the OECD WPMN Sponsorship Programme. The Nordic test programme has tested the ecotoxicity of nano-silver nanomaterials in soil and sediment. The lack of studies in the soil environment, the wide range of species and endpoints involved, incoherence in guideline use, limited reporting of parameters (TEM, SEM, DLS) and scattered results have all motivated this work. Broad aims and results will include broadening expertise, increasing input to the sponsorship programme and enhancing coordination, also to form a network that can support Nordic agencies. The testing programme also aims to develop test guidelines (TGs) that are capable of dealing with nanoparticles (NPs) and to test 
OECD TG 222 (soil) and TG 225 (sediment) for NPs and make suggestions on their adaptions. Especially the hypothesis that sediments and soils will act as sinks of NMs in the environment has motivated this work.

The approach of the test programme has been to combine tests of two TGs with worms while testing fundamentals with NPs in the TGs. Studies have also examined particle size and particle coating. Denmark (Scott-Fordsmand et al) has tested TGG 222 on the mortality and reproduction of earthworms, while Finland has been working with TG225 and the mortality and reproduction of sediment worms (Kukkonen et al). The Norwegian contribution (Oughton et al) has been on fate and uptake in organisms whereas Sweden (Hasselov et al) has concentrated on detection and characterization of NMs during exposure.

On the basis of the Nordic testing programme, developing methods further is seen necessary. As sediment and soil effects are not comparable, comparability remains an issue. Furthermore, the quantification of exposure is a major concern to be addressed. Even though challenges persist in testing nanoparticles, there is a case for optimism and we should go forward with further testing. For example, results indicate that direct addition as dry powder into soil gives the best homogenic distribution of the material.

As response to the the presentation, a representative of the EC commented that testing should prioritise NMs being sold - at the moment there are however few relevant NMs on the market.

\subsection{Environmental fate studies on NMs (Erik Joner, Bioforsk, NO and Deborah Oughton, Norwegian University of Life Sciences, NO)}

In this joint presentation Erik Joner first discussed the issue of environmental fate of NMs during the lifecycle, especially when they become waste. One of the questions was: are there nanospecific issues in the environemental fate of NMs. Again the soil compartment and effects seen in the earthworms seemed relevant. Testing in more relevant soil conditions including "ageing" was concluded to be important. In the soil studies clear effects of nano-iron (nZVI) have been seen on the plant emergence and growth. Also nano-silver seemed to cause apoptosis in the earthworms.

Deborah Oughton presented observations with silver-NMs in aquatic fate studies and effects seen in fish. It seems that nanoparticles (Ag) stay stable and dispersed especially in the Nordic humic soft waters. In par- 
ticular, the possibilities to use neutron action as a method to detect metallic NMs were discussed. The presentation also showed some results from former studies of release of particles and ions from Chernobyl accident, which can be taken as useful examples for fate studies in soil and water. In these, nano-specific issues like changes in agglomeration/aggregation, dissolution and time-course effects of ageing in soil were emphasized.

\subsection{Detection of NMs in the environment and verification of exposure (Geert Cornelis, University of Gothenburg, SE)}

Environmental risk assessment of engineered nanoparticles requires physico-chemical characterization of their particle number concentration and aggregation state in environmental media. Nevertheless, available analytical techniques are often contradictory or are not suited for determining environmental concentrations. Two techniques were proposed for sensitive and specific analysis of engineered nanoparticles in complex environmental media: field flow fractionation (FFF) combined with inductively coupled plasma-mass spectrometry (ICP-MS) and single particle ICP-MS (SP-ICP-MS).

Promises and limitations in terms of detection limits and dissolved background of these techniques were detected using acquired data on engineered citrate coated silver nanoparticles with sizes ranging between $20 \mathrm{~nm}$ and $80 \mathrm{~nm}$ in the case of SP-ICP-MS.

Two first examples of analysis in the environment were shown. While the presented techniques show great potential, detection limits in terms of size are limited to $20 \mathrm{~nm}-40 \mathrm{~nm}$ in the case of AgNP, especially when a dissolved background is present. Possible prospects for improvements were discussed of SP-ICP-MS. FFF or centrifugal-FFF (cFFF) coupled to SP-ICP-MS may provide additional information on the state of the engineered nanoparticles of which both fate modelling and exposure dose verification in the case of ecotoxicology can benefit.

The interactions of nanoparticles (NPs) and the environment were also discussed, examples including homocoagulated/heterocoagulated NPs. The partial or full sulfoxidation and effects of this on fate and toxicity have been illustrated in silver-NPs studies in Australia. 


\subsection{Inhalation of nanoparticles and health effects (Marit Låg, Norwegian Institute of Public Health, NO)}

Nanoparticles (less than $100 \mathrm{~nm}$ ) constitute the smallest fractions in ambient particulate matter (PM). Although the health effects of PM are confirmed by several studies, it is still uncertain which fraction of the air pollution is responsible for the various health effects. However, epidemiological studies indicate that the nanosized particles may have a role in particular with respect to cardiovascular effects. Inflammation is regarded as an important process in development and aggravation of both lung- and cardiovascular diseases induced by PM.

Studies on deposition of inhaled particles in the lungs of rats show that particles in the nanosize range were retained in the lung, but they are also translocated to the interstitial tissue more readily than larger particles. Especially the particles in the $10-100 \mathrm{~nm}$ size range seemed to reach the alveolar system. It seems, however, likely that two or more mechanisms of toxicity are involved in mediating heart disease by nanosized particles: i) indirect effect of pulmonary inflammation and oxidative stress ii) translocation of particles to the circulation and a direct effect on cardiac cells or endothelial cells.

Furthermore, nanosized particles have a more pronounced effect on inflammation, cell damage and cell stimulation than equal mass of particles of the same material of greater size. The higher surface area seems to be the metric driving the pro-inflammatory effects. This appears to hold true for several different materials such as carbon black, titanium dioxide, various metals and polystyrene. In addition to surface area also shape, structure and chemical composition of the nanoparticles are important parameters for eliciting inflammatory responses. In alveolar inflammation the release of IL-6 (inflammatoric mediators), immune cells and ROS may lead to inflammation and to the various diseases. Many nanoparticles seem to be mildly inflammagenic, however, they may augment lung inflammation related to pre-existing diseases such as allergy, chronic obstructive pulmonary disease (COPD) and microbial infections. Also new endpoints for the inhalation studies should be considered e.g. BAL bronchious alveoli lavage analysis.

In conclusion, it is no doubt that engineered nanoparticles have a potential to elucidate health effects. Their toxicity will also depend on the exposure to these particles. 


\subsection{Update on genotoxicity of NMs (Julia Catalán, FIOH, FI)}

Genotoxicity testing of engineered nanomaterials (NMs) involves a number of challenges. It is often not known how much of the material is taken up by the cells and if differences in intracellular pathways could explain differences in genotoxicity. The basic mechanisms (e.g. direct interaction with DNA, indirectly through ROS reaction and inflammation) of NMs genotoxicity were presented. It seems that direct interaction, for example access into nucleus or actions during cell division, and possible "Trojan horse effects" releasing the ions inside the cell seem to be possible. The genotoxicological methods that have been used in testing NMs in vitro and in vivo, considering their applicability for this purpose were summarized. Finally, the FIOH contributions to ongoing EU projects aiming at standardising toxicity testing of NMs were presented.

\subsection{In vitro studies in NM testing - Experience from NanoTEST (Lise Fjellsbø, NILU, NO)}

Nanoparticles (NPs) with their unique beneficial properties also cause a safety concern as their possible impact on human health is not known. A better understanding of how properties of NPs define their interactions with cells in exposed humans is a considerable scientific challenge. The FP7 project NanoTEST evaluates interactions of well characterized NPs with biological systems by studying the uptake and transport of NPs through biological barriers, and by addressing key endpoints of cytotoxicity, oxidative stress, inflammation, immunotoxicity and genotoxicity. We study the effects of NPs in several target systems derived from different biological systems: blood, vascular system, liver, kidney, lung, placenta, digestive, and central nervous systems by evaluating existing and developing new in vitro assays. The final goal is to develop alternative testing strategies essential for detailed risk assessment, applying high-throughput in vitro methods.

There are a number of different NP characteristics which may influence transport and toxicity, including size, surface area, coating and charge. In NanoTEST we find detailed characterization of the NPs very important to be able to compare toxicity results across different laboratories, and also to better understand their behaviour and mechanisms of action. Seven NPs have been characterized and tested; PLGA-PEO polymeric NPs (140 nm, ADVANCELL), uncoated iron oxide and oleate coat- 
ed iron oxide $\left(\mathrm{Fe}_{3} \mathrm{O}_{4}, 8+3 \mathrm{~nm}\right.$ core, PlasmaChem), titanium dioxide $\left(\mathrm{TiO}_{2}\right.$, $21 \mathrm{~nm}$, Evonik), fluorescent (Rhodamine) silica (25 and 50nm, Microspheres-Nanospheres ) and Endorem (Guerbet) as a negative control.

Until now, several in vitro methods have been investigated and/or adapted for NP testing; Fe uptake, Neutral red uptake, MTT Test, ROS production, LDH Assay, WST-1 Assay, 3H Tdr incorporation, TUNEL, glutathione thiol detection, ELISAs for cytokines and growth factors, Propidium iodide, HE, DCFDA, growth activity test, plating efficiency, signaling pathways, in vitro micronucleus test, comet assay for detection of strand breaks and specific DNA lesions and others. To be able to compare data, partners used NPs from the same batch, followed the same dispersion protocol and the same experimental design of 5 concentrations (to obtain a dose response) in each treatment. In all experiments quality controls and standards were used. Data are complete for most assays with all NPs.

\subsection{Aquatic effects and fate of nanomaterials in the Nordic environment (Jussi Kukkonen, University of Eastern Finland, FI)}

Examples of effects of fullerene and nanosilver in water or sediment tests on Daphnia magna and two benthic organism, Lumbriculus variegatus (Oligochaeta) and Chironomus riparius larvae, were presented and discussed. It was noted that NMs are not chemicals as such, and testing of them include many challenges.

Fullerene agglomerates were prepared using a water stirring method. Fullerene accumulation into D. magna was rapid during the first few hours, and based on accumulation modeling, $90 \%$ of the steady-state concentration was reached in $21 \mathrm{~h}$. After exposure for $24 \mathrm{~h}$ to a $2 \mathrm{mg} / \mathrm{L}$ fullerene solution, the daphnia accumulated $4.5 \mathrm{~g} / \mathrm{kg}$ wet weight. Daphnids exposed to $2 \mathrm{mg} / \mathrm{L}$ fullerenes for $24 \mathrm{~h}$ eliminated 46 and $74 \%$ of the accumulated fullerenes after depuration in clean water for 24 and $48 \mathrm{~h}$, respectively. Transmission electron microscopy revealed that the majority of the fullerenes present in the gut of daphnids were large agglomerates.

L. variegatus were exposed to 10 and $50 \mathrm{mg}$ fullerenes $/ \mathrm{kg}$ sediment dry mass for $28 \mathrm{~d}$. These concentrations did not impact worm survival or reproduction compared to the control. Feeding rates were also slightly decreased for both concentrations indicating fullerenes' disruptive effect on feeding. 
Chironums riparius were exposed after allowing suspended fullerenes to settle down creating a layer of $\mathrm{nC}_{60}$ on top of the sediment, another environmentally realistic exposure method. To test the hypothesis that higher food concentrations will reduce toxic responses, two food concentrations were tested $(0.5 \%$ and $0.8 \%$ Urtica sp.) in sediment containing fullerene masses of ( 0.36 to 0.55$) \mathrm{mg} / \mathrm{cm}^{2}$ using a 10 -d chronic test. In the $0.5 \%$ food level treatment, there were significant differences in all growthrelated endpoints for fullerene exposed organisms compared to controls. Fewer effects were observed for the higher food treatment. Fullerene agglomerates were observed by electron microscopy in the gut but no absorption into the gut epithelial cells was detected in either organism.

Electron micrographs of $L$. variegatus also indicated that $16 \%$ of the epidermal cuticle fibers of the worms were destroyed in the $50 \mathrm{mg} / \mathrm{kg}$ exposures, which may make worms susceptible to other contaminants. For $C$. riparius, microvilli were damaged and significantly shorter. The potential toxic effects of fullerenes to $C$. riparius appear to be caused by physiological changes. 


\section{Break-out groups on test guidelines and their applicability to assess NMs}

Three break-out groups discussed pre-given questions on test guidelines and their applicability to assess NMs. Two of the groups focused on toxicology, while one concentrated on ecotoxicology. Their conclusions are presented below.

\subsection{Existing test guidelines and new guidance for the hazard and safety assessment of NMs}

Can we manage hazard and safety assessment by using existing test guidelines or only by developing new technical guidance on how to handle and characterise the exposure to NMs?

\section{Toxicology group 1}

- We have to start with existing test guidelines to gather experience. Guidelines can then be modified if necessary

- While developing guidelines is imperative, more common knowledge is needed to achieve comprehensive results

- We need to decide what extensions are necessary in order to establish whether existing guidelines are valid for nanoparticles (NPs)

- Determining whether the OECD test guidelines are suitable to be used for NPs is necessary

- Plans for testing in vitro tests exist. This can be achieved only by developing new technical guidance which will be a laborious endeavour

- Normally in vitro tests are used to assess genotoxicity. However, currently in vivo tests are needed to assess genotoxicity of NMs. It thus follows, that the same thinking cannot be applied to chemicals and NPs

- Some of the existing tests are compatible with NPs but there are also many that are not applicable to NPs. Practical problems with NPs remain in these tests, including removal of the interference of NPs with the endpoint detection from the tests. This makes exposure problematic 
- At the moment, testing takes a case-by-case approach. With NPs, a more flexible approach is needed

\section{Toxicology group 2}

- Hazard and safety assessment can be managed if the new technical guidelines address physical interaction, including agglomeration

- In vitro assays can be used only for genotoxicity

- Preparation of samples for exposure is important

- It is most important to characterize exposure, instead of being too specific in the guidelines

\section{Ecotoxicology group}

- While existing guidelines are adequate for hazard and safety assessment to some extent, traditional endpoints may be insufficient with NMs

- There is some need for modification but the existing test guidelines provide a good starting point

- Particle characterization must be ensured. Constant exposure is impossible, so modifications must account for this

- Is TG acceptance just a question of managing exposure? Alternatively is it about the preparation of NP samples? Should an agglomeration test be imposed?

- Matrices are a further challenge. How are NPs to be mixed into matrices? Should reference compounds exist for NPs?

- Should test duration be extended to account for slower uptake? NPs age differently in soil compared to traditional chemicals (increase rather than decrease). Furthermore, speciation over time is important to describe. Bioaccumulation needs to be regarded from a new standpoint: revision is underway anyway

- Longer test duration was recommended to better adapt to NPs. Should different aspects be classified as optional and mandatory?

\section{Summary:}

Groups agreed that while development of guidelines is necessary, existing guidelines are an adept starting point for safety and hazard assessment. Flexibility in guidance was emphasised by all groups. The existence of technical and conceptual challenges to the existing guidelines was also observed. 


\subsection{Technical guidance for specific areas of testing}

Should technical guidance be developed for specific areas of testing e.g. soil studies, aquatic studies or inhalation and skin absorption studies?

\section{Toxicology group 1}

- At the moment, generalisation is difficult and proceeding case-bycase with NPs is preferable

- General issues to be addressed include characterisation, size, size distribution and dosimetry among others

- Guidance should be flexible

- Instead of requiring adherence to strict technical guidance, guidance could allow some freedom of choice with recommendations on procedure

- Controls (positive/negative) are important

- Trouble shooting notes would be good practice in order to collect and share experiences from tests conducted

\section{Toxicology group 2}

- The property of exposure needs characterization

- Each type of exposure should have separate guidance

\section{Ecotoxicology group}

- Soil/sediments and aquatic environments cannot be covered by the same TG

\section{Summary}

While one of the groups elaborated their views at more length than the others, there was agreement that different guidance for different areas of testing is needed.

\subsection{Guidance based on NM groups}

Should guidance be based on NM groups (e.g. metal, metal oxide NMs)?

\section{Toxicology group 1}

- Guidance should be based on NM groups if nanomaterials (NMs) can be grouped in a meaningful way

- Grouping may be practically difficult and thus faces the risk of being misleading 
- Grouping is commendable if it is possible by using physico-chemical characteristics

- Would specific guidance then exist for metals and carbon nanotubes?

- NPs cannot be grouped yet, at least in the case of metals

- Even though uncertainty remains an issue, some data is appearing. Metal NPs may have similar features (e.g. the ion release), while similar carbon nanotubes have similar features

\section{Toxicology group 2}

- NM groups do not seem the best basis for guidance

- Nevertheless, grouping could be beneficial for compounds for which enough specific knowledge exists

- The success of grouping depends of the broadness of the guidance document

- Relevance of grouping NMs is questionable

\section{Ecotoxicology group}

- Organic/inorganic and different uses (e.g. suspensions, powders) are possible bases for NM groups

- Dealing with coatings is problematic

- From a regulatory viewpoint organic/inorganic is not useful. Grouping based on use, volume or properties could be better for regulatory purposes

\section{Summary}

Agreement on the practical difficulty of grouping nanomaterials existed across all groups. Nevertheless, it was seen that if grouping could overcome these practical hurdles, it would be desirable.

\subsection{Nanospecific endpoints}

Are there new nano-specific or nano-relevant endpoints in the areas of physico-chemical properties, environmental fate (degradation and accumulation), ecotoxicology or human health effects?

\section{Toxicology group 1}

- The specific endpoints for NPs remain unclear. Options include surface parameters, zeta potential, crystal form, aggregation/agglomeration, size and size distribution

- Also media should be characterized, including protein content in media

- Characterisation should be done for the NM product in test media 
- With regards to human health effects, we lack guidelines. For example, where do the particles go in the inhalation exposure (adsorption, metabolism etc.)?

- Some endpoints on the abiotic degradation, such as hydrolysis, are relevant for NMs but at present can be waived as they are not required under REACH for certain substances (e.g. metals)

\section{Toxicology group 2}

- Surface reactivity is a potential concern with regards to physicochemical properties

- The distribution of nanoparticles in the body is a potential new endpoint that demands analyzing equipment

- More sensitive endpoints could include gene expression and proteomics

- N.B. Ecotoxicology group 1 did not answer the question due to time constraints

\section{Summary}

Clear conclusions on new nano-specific endpoints failed to emerge. However, many of the toxicological, ecotoxicologican and environmental fate endpoints are nanorelevant. New endpoints and test methods are needed for physic-chemical characterization of NMs.

\subsection{Test Guideline Modification and the Mutual Acceptance of Data}

How do potential modifications of the test guidelines affect the Mutual Acceptance of Data (MAD)? How much can we divert from the standard test guidelines?

\section{Toxicology group 1}

- If the modification is added to the guideline it will be in line with MAD (mutual acceptance of data)

- Maybe a special solution could be used for NMs to speed up the process of MAD

- N.B. Toxicology group 2 and Ecotoxicology group 1 did not answer the question due to time constraints 



\section{Presentations on the regulatory possibilities for EDCs and NMs}

\subsection{Outcome of the three Nordic workshops on EDCs held in Denmark in 2010 (Sofie Christiansen, DTU, Pia Juul Nielsen and Rikke Holmberg, Danish EPA, DK)}

The joint presentation provided an overview on the conclusions of three Nordic Workshops held in Denmark in the autumn of 2010.

A typology for EDC criteria as confirmed, suspected or potential endocrine disruptor was presented. Combined effects, the topic of one of the workshops, including dose addition with the recommended model were discussed. The discussion also addressed risk assessment quota from different sources for one chemical. The extra safety factor of 10 was seen important.

Another workshop addressed risk communication and soft regulatory measures. The workshop had reached the conclusion that the public should always be consulted in creating legislation. The Nordic countries' experiences with soft regulatory measures further supported this conclusion.

The final workshop on the regulation of combined effects also outlined the status of EU work. It was noted that there is currently a compilation of reports and on-going work. A forthcoming EC report assessing existing legislation is expected to relate how legislation can address combined effects. In addition to the EU work, the World Health Organisation (WHO) framework remains an important source of expertise. 


\subsection{Regulation of combined effects - status of the EU work (Rikke Holmberg, Danish EPA, DK)}

The presentation reviewed the status of work being done in the EU on the regulation of combined exposure to chemicals from different sources and pathways. Terminology and methods used to assess risk from combined exposure were presented. Important, recent reports within the field were also highlighted. The recent draft opinion regarding chemical mixtures from the 3 scientific committees in the EU and the $4^{\text {th }}$ report on the implementation of the Community strategy for endocrine disrupters were also addressed. The Danish view on critical issues within the field and possible ways forward under the upcoming Danish Presidency were highlighted

\subsection{Registration of $\mathrm{ZnO}$ in REACH - is it sufficient for safety evaluation of nano $\mathrm{ZnO}$ ? (Katarzyna Malkiewicz, Kemi, SE)}

An overview of the practical training in toxicological risk assessment (RA) of chemicals realized at the Swedish Chemicals Agency (Kemi) as a part of European Toxicology Risk Assessment Training (TRISK) was presented. The work in this project had double focus: to analyze toxicity data registered for Zinc Oxide ( $\mathrm{ZnO}$ ) at ECHA within REACH and discuss the approaches for RA taken by the industry; and to collect publicly available data relevant for $\mathrm{RA}$ of nano forms of $\mathrm{ZnO}$ and attempt the RA to the extent these limited data allow.

This project specifically aimed at: 1) Clarification of how nano forms of $\mathrm{ZnO}$ have been registered under REACH; 2) Analysis of the extent of data concerning physico-chemical properties and human health hazard that have been registered for both "bulk" (macro and micro-size particles) and "nano" $\mathrm{ZnO}$ and identify data gaps; 3 ) Analysis of assumptions and approaches in the RA; 4) Critical revision of those approaches in light of independently collected scientific literature on nano-specific properties versus bulk properties in the context of toxicological effects and / or fate or exposure aspect.

The following conclusions of the project were presented:

1. Registration within $\mathrm{REACH}$ of $\mathrm{ZnO}$ is based on the dossier containing information on different zinc compounds and different forms, bulk and nano, and the consortium includes entities (producers or importers) for whom any of the forms is relevant. This implies that nano $\mathrm{ZnO}$ has been considered by the registrant the same substance 
as bulk counterpart and registered within the same dossier. As an example, one producer has registered nano $\mathrm{ZnO}$ within the production tonnage band 100-1,000 tonnes/year/manufacture

2. 74 studies were selected and registered, as relevant for human hazard assessment. Majority of the studies were performed in 70's and 80 's. Only 15 studies with exposure to nano $\mathrm{ZnO}$ were registered, with the scope of endpoints limited to: inhalatory and dermal kinetics, and acute and repeated inhalatory toxicity. Some of those studies suffer from the lack of characterization of the nano $\mathrm{ZnO}$

3. The RA within REACH registration was based on the assumption that zinc cation $\left(\mathrm{Zn}^{2+}\right)$ is the mediator of the biological activity of zinc compounds, and the dissolution rate of $\mathrm{Zn}^{2+}$ from those compounds will determine the activity / toxicity. The regulatory homeostatic mechanisms for $\mathrm{Zn}^{2+}$ in humans and other organisms have been considered efficient to limit the intake or promote excretion of $\mathrm{Zn}$ during high exposure. The results of the inhalatory toxicity due to the exposure to nano $\mathrm{ZnO}$ have been considered by the registrant not relevant for the consumer exposure

a) The oral dietary supplementation of human volunteers study has been chosen by the registrant as a critical study (NOEL $0,83 \mathrm{mg} / \mathrm{kg}$ bw/ day) and assessment factor of 1 (no need for interspecies extrapolation and time extrapolation considered not relevant). Derived No Effect Levels (DNELs) for systemic effects after oral, dermal and inhalatory exposures for consumers and workers have been developed based on the estimated differences in the kinetics of absorption for different routes. For dermal and inhalatory exposures differences between solubility of different compounds resulted in separate DNELs for soluble compounds and for insoluble (or slightly soluble)

4. In the light of limited studies collected independently, by the presenter, from the open sources it has been discussed within this project: i) that the studies registered within the dossier have not included all available and relevant studies concerning the effects of $\mathrm{ZnO}$ in nano forms. Over 30 additional studies with nano $\mathrm{ZnO}$ were collected with the following endpoints: dermal penetration ( 9 studies), tissue distribution (1 study), acute oral ( 3 study), acute inhalatory ( 2 studies), repeated inhalatory ( 6 studies), mutagenicity (8 studies), phototoxicity ( 1 study), other (4 studies)

a) The acute oral exposure study indicated that nano $\mathrm{ZnO}$ at lower doses $(1 \mathrm{~g} / \mathrm{kg})$ caused changes in biochemical and enzymatic parameters indicating cardiovascular, hepatic and /or thrombotic ef- 
fects. The relevance of those findings is not fully understood however this level meets the criteria for Specific Target Organ Toxicant STOT (cat 2) classification ( $2000 \geq \mathrm{C}>300 \mathrm{mg} / \mathrm{kg}$ body weight)

b) The assumption that $\mathrm{Zn}^{2+}$ is a single mediator of zinc compounds activity may not fully cover the kinetics and mechanisms of nano $\mathrm{ZnO}$ activity. Some evidence suggests that for nano structured $\mathrm{ZnO}$ biological activity may not be solely based on the externally released $\mathrm{Zn}^{2+}$. Study indicated that for toxicity in human colon cancer cells, the direct particle - cell contact was required. Another study on macrophage response to $\mathrm{ZnO}$ nanorods indicated that cell adhesion and viability correlated to both nanotopography and dissolved $\mathrm{Zn}^{2+}$. The regulatory homeostatic mechanism may also be challenged due to the rapid intracellular increase of $\mathrm{Zn}^{2+}$ due to the particle active intake and rapid intracellular dissolution

c) The relevance of the inhalatory studies on the nano $\mathrm{ZnO}$ cannot be ruled out for all scenarios. The nano $\mathrm{ZnO}$ based products that could potentially result in inhalatory exposure to nano $\mathrm{ZnO}$ are already on the market (cosmetics: sunscreen spray, deodorant, shaving sprays), and new type of products based on the anti-UV, antibacterial, antifungal or water-resistance properties could potentially result in other spray type products for treatment of surfaces, clothes etc)

- The ConsExpo modeling of inhalatory exposure to nano $\mathrm{ZnO}$ following the 1 minute use of the spray application containing $25 \%$ of $\mathrm{ZnO}$ in a small room with middle ventilation range resulted in high peaks of estimated concentrations in a range of over $100 \mathrm{mg} / \mathrm{m} 3$. It was considered probable that this value is overestimated, and experimental confirmation would be desired. This value exceeds the Derived No Effect Level for consumers $(2.5 \mathrm{mg} / \mathrm{m} 3)$ and is in a range of levels associated with health effects in human short exposure situations. Based on this assessment it has been recommended by the author of this report to avoid indoors spray applications containing high concentration of nano $\mathrm{ZnO}$, before targeted and refined RA has been performed 
In conclusion this analysis reveals that the data registered for $\mathrm{ZnO}$ within REACH is not sufficient for the RA of nano forms of $\mathrm{ZnO}$. The assumptions used by the registrant for RA and derivation of safe limits may not be adequate for nano $\mathrm{ZnO}$. Requesting of further nano-specific data in connection to the substance evaluation as a further process under REACH is therefore recommended by the presenter. 



\title{
6. Presentations on regulating NMs
}

\author{
6.1 Summary on the TG applicability and TG/GD \\ needs (Poul Bo Larsen, Danish EPA, DK and Jukka \\ Ahtiainen, Tukes, FI)
}

The presentation delivered a summary on test guideline (TG) applicability and addressed the necessity of new TGs and Guidance Documents (GD). The overriding issue was whether we can manage hazard and safety assessment by using existing test guidelines or only by developing new technical guidance on how to handle and characterize the exposure to NMs.

It was seen that there is no need for new TGs at the moment. Instead, guidance documents should be developed. Exposure issues were seen most relevant to hazard and safety assessment, broadly including sample preparation and what happens during the test-dynamic systems. The presenters raised the issue of how to ensure and verify constant concentrations and challenged its desirability. The need for including new endpoints in GDs was also discussed. It was noted that as a consequence of ageing of NMs, an underestimation of their toxicity may occur. While case-specific guidance was seen reasonable in some cases, agreement on the use of GDs under the MAD principle is necessary, especially when adding optional, new endpoints for NMs.

It was argued that technical guidance should be developed for various areas of testing, including soil studies, aquatic studies and inhalation and skin absorption studies. While Guidance Notes on Sample Preparation and Dosimetry (GNSPD) are likely to evolve into several GDs in many areas, there are general areas encompassing all areas of testing.

Guidance based on NM groups was also seen feasible, especially when more knowledge on suitable groups has emerged. Grouping by uses and activities or grouping by features, like HARN (High Aspect Ratio NMs, are options for future guidance.

The existence of new nano-specific endpoints was emphasised. Especially in the area of physico-chemical properties, there is a need for new TGs. For environmental fate, including degradation and accumulation, detection remains a major issue. Understanding processes such as deg- 
radation and biodegradation constitutes a further challenge. For both ecotoxicology and human health effects, there is scope for adding new measurements. In the case of human health, BAL in inhalation tox is a possible new measurement.

\subsection{Current regulatory views in the EU (Henrik Laursen, DG ENV, EC)}

The presentation outlined key EU actions and views on the regulation of nanomaterials. Intensification of EU action on nanomaterials is marked by the 2004 'Towards a European Strategy for Nanotechnology' Communication from the Commission. Since then, the EU has taken an actively communicative approach to nanomaterials, emphasising stakeholder consultation in its actions. The European Parliament disagrees with the Commission view that "current legislation covers risks of nanomaterials" and concluded in a 2009 resolution that due to the lack of appropriate data and risk assessment methods, nano risks cannot be adequately addressed. Specific nano requirements have been considered in cosmetics, food and waste regulation with mixed results - the Cosmetics Regulation has proven the most successful case up to date.

Current EC tasks include the finalization of the RIPoN and the $2^{\text {nd }}$ regulatory review of nanomaterials covering all relevant legislation. The European Parliament has also requested the Commission to evaluate the need to review REACH, especially with reference to the need of more simplified registration of nanomaterials with registration requirements below the current 1 tonne per year and all nanomaterials registered as new substances. A report on nanomaterial types and uses and safety aspects is also soon to be made available. The report is particularly important against the speculation that rather few NMs are produced and used in large volumes in the European market. At council request, the report will also consider an EU nano reporting system, possibly to use the REACH and CLP systems or a separate system. The Commission will also be reviewing the adecuacy of nano-relevant REACH registration dossiers for the content on health and safety information specific to nanomaterials. It aims to identify possible legal and technical gaps in them and find means to rectify gaps and assess their consequences.

A nanomaterial definition is a further, notable development and is to be adopted on the $18^{\text {th }}$ of October 2011. The Draft Proposal subject to public consultation received input from 195 stakeholders. While the definition is based on available scientific knowledge (particularly JRC 
report, SCENIHR opinion), it needs to be pragmatic to be able to determine when a material should be considered as a nanomaterial for legislative and policy purposes in the EU.

In conclusion, competitiveness and innovation are fundamental to the EU - uncertainty challenges these goals by reducing consumer demand as well as by reducing supply by decreased investment. Uncertainty should thus be diminished by ensuring safety, sustainability and the application of the precautionary principle in conjuction with facts. The ongoing legislative review aims to find out whether legislation is working for these goals.

\subsection{Registrations of NMs (Marita Luotamo, ECHA)}

The presentation provided discussed experiences on nanomaterials (NMs) under REACH. According to the European Chemicals Agency (EC$\mathrm{HA}$ ), in principle NMs are covered under substance definition in REACH as either substances on their own and registered as such, or nanoforms of a substance included in the dossier of the corresponding bulk substance. It was however noted that the REACH lacks specific requirements for nanomaterials.

The presentation advocated a case-by-case approach to a nanomaterial's registration and safety assessment. Furthermore, registrants are encouraged to include information in registration and CLP dossiers. The 5.2 version of the IUCLID chemicals database includes new features enabling registrants and notifiers to indicate nanomaterial as the form of the substance, allowing for enhanced collection of nano-specific information.

At Commission request, ECHA has undertaken inventory work on nanomaterials' registration and notification with information on specified uses. So far very few registration dossiers received have contained nanomaterial-specific info. In addition to participating in the RIP-oN 1, 2 and 3 work, ECHA is working on a joint nano-project with JRC including detailed screening of information requirements provided for the identified REACH registration dossiers and making recommendations for REACH-specific adjustments of information requirements. ECHA is also engaged with evaluating nanomaterial-specific testing proposals and will eventually accept or reject proposed tests, modify their conditions and potentially request additional testing. A compliance check will then verify compliance with information requirements and result in a formal decision, requesting further information if necessary. 


\subsection{Towards harmonization of national databases for NMs on the market (Juan Pineros, MoE, BE)}

Voluntary reporting systems on nanomaterials have not proven successful. Harmonisation of databases is however of great importance - a joint project by France, Italy and Belgium is working towards this goal between the three countries. While Belgium has made a nanomaterials database compulsory starting from 2012 and the Grenelle law of 2011 is driving a mandatory reporting scheme in France, Italy is implementing a voluntary reporting scheme on nanomaterials, with potential to evolve into being compulsory.

While the $2^{\text {nd }}$ Environment and Health Action Plan invited the Commission to evaluate the need for developing specific measures for nanomaterials relating to risk assessment and management, including the further development of a harmonized database for nanomaterials, the Environment Council has recently reiterated this invitation. The Commission is currently assessing the added value of such a plan.

Aims and potential benefits of a common, harmonised database are wide-ranging. Such a database would enable gathering data on the nanomaterials produced and sold on the market. It would also allow for approximate estimations on occupational, consumer and environmental exposure as well as enable traceability of nanomaterials. On a national level, a database would help national authorities in establishing adequate risk assessment and management systems. The knowledge gained could then be used for the improvement of the legislative framework, even at the EU level.

Comprehensiveness and links to other frameworks are seen desirable while creating reporting mechanisms for nanomaterials. It was recommended that a potential harmonised database should cover all EU legislation and have links with REACH and its risk management actions (authorisation, restrictions). Furthermore, the database should enable exact NM identification. Substances, mixtures, articles and consumer products with intended release of NMs (not covered by REACH) are all among items to be declared to the database. The obligation to declare is borne by producers, importers, distributors, downstream users and potentially end of life users and recyclers.

Belgium, France and Italy all employ different implementation and enforcement tools in relation to their reporting schemes. Despite differing national arrangements, the overarching aim of the countries' reporting and harmonisation endeavours is to collect data and enable traceability of NMs. While not an obstacle to market access, data collection 
constitutes a first tool to react to a nano-related risk if one were to emerge. With the lack of a harmonised EU reporting framework, cooperation between member states seems to be the way forward both for the sake of harmonisation and contribution to the discussions on improving the legislative framework on nanomaterials.

\subsection{French reporting scheme for Nanomaterials (Clarisse Durand, Ministry of Ecology, Sustainable Development, Transports and Housing, FR)}

The origins and outline of the French reporting scheme for nanomaterials were presented via teleconference. In 2007, national brainstorming about sustainable development was organised by the French government. The "Grenelle de l'environnement" involved all relevant stakeholders, including state and regional administration, industry, employees, NGOs, elected representatives and scientific experts. A commitment regarding nanomaterials was formulated expressing the need to anticipate the risks linked to the production and the use of manufactured nanomaterials (commitment ${ }^{\circ} 159$ ).

This commitment was implemented through the articles of Grenelle Law I (2009) and Grenelle Law II (2010). In compliance with article 42 of the Grenelle Law I, a national public debate on nanotechnology was organised between October 15th, 2009 and February 24th, 2010. The article also gives details on the mandatory reporting scheme of nanomaterials. The quantities and uses of nanomaterials will be reported and made available to the public and consumers. This article specifies the need to develop a methodology for assessing risks and benefits associated with these substances and products and to improve information on risks and protection measures. Article 185 of the Grenelle Law II details the reporting scheme, including identity of nanomaterials and their uses, quantities produced, imported or distributed and identity of downstream users. The reporting scheme aims at improving the traceability of the nanomaterials. Some of the reported information will be made available to the public (identity of nanomaterials and their uses). The law specifies that available data on hazards and exposures could be requested by the authority. This procedure aims at gathering a minimum level of information, it is not a risk management measure.

The conditions of execution have to be specified in a decree. The decree makes a number of clarifications. The decree employs a working definition for "substance at the nanoscale" which will be replaced when 
a definition from the European Commission is available. Declarants, including manufacturers, importers and distributors, shall report each year. The threshold for the declaration is set at 100 grams. The decree gives possibility to require the confidentiality of declarants' data.

On June 23, 2011, the decree was notified in accordance with the 98/34/EC Directive. Observations from Germany, UK and the European Commission were received. Now that the decree has been notified, it can be forwarded to the Conseil d'Etat (highest administrative jurisdiction in France), in order to be published by the end of the year. The reporting scheme will start in 2013 and will relate to nanomaterials that were produced, imported to France or distributed in 2012.

By the means of a basic report and sustainable data collection tools, it will ensure a better market knowledge and traceability of nanomaterials in EU market and permit a rapid and adequate response if ever a specific risk of a nanomaterial emerges. More information on nanomaterials will also be provided to consumers and to workers (nanomaterial identity and its uses). However, commercially sensitive information will not be disclosed.

The mandatory reporting scheme is a French initiative, but it is undertaken with other Member states, and with a willingness to contribute to improvement of the legislative framework at the EU level.

\subsection{Example(s) on NM safety assessment and RMM (Nicole Palmen, RIVM, NL)}

Engineered nanoparticles and nanomaterials (ENP) are used for example in food, coatings and electronic equipment. Workers in both industry and research/development may be exposed to ENP. In a risk assessment, exposure of workers to a hazardous compound (ENP) is compared with health based occupational exposure limits (OEL). Since the body of knowledge on ENP is limited, it is not yet possible to derive OELs for all ENP. Due to the need to control risk, provisional nano-reference values (P-NRV) were derived - they can be used as a pragmatic benchmark level. In case of exposure above the P-NRV, exposure reducing measures should be taken immediately. Since, exposure below P-NRV does not guarantee safe working conditions, exposure-reducing measurements should also be considered for exposures below the P-NRVs, according to the ALARA principle (As-Low-As-Reasonably-Achievable).

Quantitative assessment of ENP was done during an electro spinning process and downstream use in construction, car repair, painting and paint sealant. From these measurements we learn that exposure to nano- 
particles is highly dependent on the application technology. Background exposure to nanoparticles may interfere with the measurements. Working indoors leads to much higher ENP concentrations compared to outside work, especially when it is windy. Real time measuring devices do not differentiate between ENP and background, so additional sampling and electron microscopic analysis is necessary to identify ENP. Agglomerated nanoparticles may not be detected, which may cause an underestimation of the exposure to nanoparticles since agglomerates may fall apart into nanoparticles the lung. Since quantitative measurements are difficult to perform and expensive, qualitative tools were developed to help employers and employees to perform a risk assessment. These tools are based on the control banding principle which means that both hazard and exposure are classified in several bands, leading to a matrix with several risk bands. The risk bands are then coupled to risk management measures according to the industrial hygienic strategy. Guidance for working safety- and decision matrix control (risk) levels and control measures including the training of workers are very important.

\subsection{Nanotoxicology: Science at the interphases, Estonian perspective (Kaja Kasemets, National Institute of Chemical Physics and Biophysics, EE)}

Engineered nanoparticles have received increasing interest in many fields (consumer products, industry, medicine) due to their novel physicochemical properties compared to the same bulk material (microsized), mostly due to the remarkably increased specific surface area and reactivity. At the same time, these changes could also be responsible for a number of biological interactions on protein, cellular, tissue and organ levels that could lead to toxic effects. Despite the rapidly progressing nanotechnological research, there are remarkable knowledge gaps concerning the physicochemical interactions at the nano-bio interface and respective toxic outcome. The adequate toxicological information on NPs is crucial to ensure successful commercialization of nanotechnology.

Since 2006, the research of the Lab in NICPB led by Dr. A. Kahru has focused on ecotoxicology of synthetic nanoparticles (NPs), mostly $\mathrm{TiO}_{2}, \mathrm{ZnO}$ and $\mathrm{CuO}$ NPs. The group has been developing a combined bio-analytical approach for the profiling of toxicological properties of metal oxide NPs. For that, the traditional medium to high-throughout in vitro assays with pro- and eukaryotic organisms (bacteria, yeast, algae, protozoa and crustaceans) have been applied comparing the NPs to their bulk counterparts, 
and by evaluating the contribution of dissolved metal ions detected by gene-modified metal-specific biosensors to the overall toxicity.

NICP research has shown that (a) $\mathrm{ZnO}$ and $\mathrm{CuO}$ NPs were toxic to bacteria, yeast, protozoa and crustaceans, while $\mathrm{TiO}_{2} \mathrm{NPs}$ didn't show any observable toxicity even at $20000 \mathrm{mg} / \mathrm{l}$, with the exception of algae Pseudokirchneriella subcapitata (72-h $\mathrm{EC}_{50} 9.7 \mathrm{mg} / \mathrm{l}$ ), (b) $\mathrm{CuO}$ NPs showed higher toxicity compared to their bulk counterparts, while the ZnO NPs and bulk formulation showed comparable toxicity, (c) the ZnO NPs (and bulk form) toxicity was caused by the dissolved Zn-ions, and (d) CuO NPs toxicity to algae and bacteria was caused mainly by the dissolved ions, but to yeast Saccharomyces cerevisiae, crustaceans and protozoa Thamnocephalus platyurus, the $\mathrm{Cu}$-ions didn't explain all the toxicity. We showed that the CuO NPs toxicity to yeast, protozoa and crustaceans was caused also by the ROS since the oxidative stress markers as decrease in glutathione concentration, peroxidation of cell membrane and immune-system imbalance, respectively, was recorded.

Further research has been focused mainly on the elucidation of how the different physical-chemical properties of metal based NPs (e.g. Ag and $\mathrm{Au}$ NPs, quantum dots etc) determine their nano-bio interphases and toxic nature using traditional (eco)toxicological and also novel genemodified bacterial and yeast based in vitro test systems. 


\section{Discussion and views on Nordic possibilities in regulating NMs}

- The main objective of the discussion was to discuss how Nordic countries can build common views on OECD and EU work on regulating nanomaterials

- A panel was made up of the following participants: Henrik Laursen (EC), Juan Pineros (BE), Peter Kearns (OECD), Poul Bo Larsen (DK) and Jukka Ahtiainen (FI). The discussion was lead by Flemming Ingerslev (DK). Other participants were also invited to participate in the discussions

- The conclusions of the discussion are presented below

\subsection{The OECD Sponsorship Programme and its progress}

There are huge expectations on the OECD testing of 13 nanomaterials for various endpoints in order to get basic knowledge on:

- what possible hazards we are facing with NMs

- the applicability of existing OECD test guidelines for testing chemicals

- the needs of new tests or guidance documents for using the existing TGs

The data from the ongoing explorative phase 1 for possible hazard identification is not yet completely available but we should start already planning for phase 2 , where the data produced should also be suitable for risk assessment. The phase 2 testing should be guided by some kind of testing strategy (or Conceptual Framework like for EDCs) which should be developed based on the existing data. 


\subsection{TG and GD development}

In general, the OECD guidelines are applicable for investigating the health effects, ecotoxicity and environmental fate of nanomaterials with the important proviso that additional consideration needs to be given to the physicochemical characteristics of the material tested, including dosing. In some cases, there may be a need for further modification to the OECD guidelines. Preparation of samples and dose administration are critical considerations for the tests and therefore guidance has been developed on sample preparation and dosimetry for the safety testing of nanomaterials. The preliminary review of OECD-WPMN is consequently seen as a "living" document, highlighting the feasibility of various approaches and allowing for continuous updates, given the rapid developments in this area.

There was a consensus that only very few possible new nanospecific endpoints (measured variables) are needed for the NMs to be added to the Test Guidelines or developed as new Test Guidelines. These new nanospecific needs are mainly in the area of physico-chemical characterization. However, some of the endpoints in existing Test Guidelines are more nanorelevant than others, for example BAL (bronchious alveolar lavage) in inhalation toxicity testing. In the area of ecotoxicity most of the existing endpoints are also nanorelevant and in the area of environmental fate testing the detection and characterization of NMs in the environmental media or in tissues is the challenge.

\subsection{REACH implementation}

The information submitted in the registration dossier for a nanomaterial, as part of the bulk registration or on its own, needs to comply with the information requirements and, if relevant, the CSR requirements for all the registrant's identified uses of the nanomaterial.

There is no one-size-fits-all solution to treating nanomaterials as forms of a bulk substance or a separate substance. Further practice needs to evolve on developing rules on how size should be used as a characterizer and when could it be used as an identifier. The Nordic countries may have differing views on whether NMs should be always registered as substances of their own and considered as new substances. However, if this were to be the case, the data requirements based on tonnages should be reconsidered.

If specific substance identification rules for nanomaterials are developed, they must be consistent with practices for substances in general. Such rules need to maintain a certain degree of flexibility to allow use of 
the most practical solutions, provided that the information is relevant and complete for all forms of the substance, and that safe use is ensured.

REACH obliges the registrant to ensure that his registration(s) demonstrate(s) that all forms of the substance in his dossier(s) can be used safely. The question of substance identity is not critical in this regard. The focus of attention should therefore be on ensuring that the submitted data are applicable or appropriate for the all form(s) covered in a dossier(s) in question and on ensuring that the registrant has provided all relevant information to allow the safe use of the substance by the downstream users and consumers. However, there are concerns amongst the Nordic countries whether industry would comply with this properly. Only 3 registrants out of 46 with NM use of the same substance had indicated the nanomaterial use in IUCLID at the first registration in 2010.

Standard information requirements, as described in the Annexes VII - XI, apply equally to nanoforms and bulkforms. The registrant has to make sure that in case tests are performed, these must be representative of the form(s) of the registered substance. Alternatively when any kind of read-across (with safety factors) is used between the forms, the registrant has to make sure that this is scientifically justified. However, it was concluded that nano-specific data requirements would need new tonnage triggers and data requirements. This would also be the need for a common registration.

ECHA has now been invited to further assess the relevant submitted dossiers in a "bottom-up" process to build up more knowledge and experience on substance identification in the registration of nanomaterials. If appropriate, ECHA should use this experience to develop further practical rules in co-operation with the European Commission, Member States and stakeholders. Such a bottom-up process should significantly contribute to a better understanding on how nanomaterials should be treated within the REACH framework.

This could be perhaps supported by Nordic countries as an interim solution. However, the revised ECHA Guidance on registration should make explicit, that the registrants and SIEF should address and assess also all the relevant uses of NMs of that particular substance. This demand should be very visible and clear probably under the title "What to register".

It was also proposed that if a member state's regulators have doubts that the safety assessment of a NM form is not adequate, these substances (e.g. the case of ZnO; having the nanoform in the market) could be raised into the CORAP process by a member state.

It was also discussed whether a separate regulation for nanomaterials would be more appropriate, in order not to make changes within REACH. 
Based on the experiences in the RIP-oNs and the experiences from the OECD sponsorship programme, a future task for Nordic cooperation could be to start work on examining specific triggers for data requirement and a testing strategy for nanomaterials.

\subsection{NM product labelling and registers}

There was a consensus that ideas on possible product registers for products containing NMs could be supported for traceability of NMs through their life-cycle. However, we should be able to make best use of our existing product registers in the Nordic countries. Furthermore, the register system should be complementary and not amount to duplication of REACH registration.

The idea of product labelling could also be supported for consumer transparency and giving the freedom of choice to the consumer. This would then also require better communication for society to gain an understanding of what this kind of labelling means.

\subsection{Establishing a Nordic Regulatory NM network}

The idea of strengthening Nordic cooperation in the field of nanosafety was supported. This should bring together research groups and regulators. Regulatory views could thus be better discussed and coordinated if needed. The core of this nano-group should also coordinate NM related work in all NKG groups.

If Nordic countries have reason to doubt the adequacy of NM safety assessment in registration and one of the countries would take this to the CORAP-process for substance evaluation, there should be strong Nordic back-up and resources for this process.

Starting a TG/GD project in the OECD test guideline programme was discussed as a concrete idea for future regulatory cooperation. The meeting identified two possible fields where there is need for work and Nordic scientific capacity. For ecotoxicology, the development of Guidance Document(s) for soil and sediment toxicity could be such an area. In the human health area, the knowledge on genotoxicity assessment could be clearly identified. One possibility is to get involved with the development of a Comet assay for an OECD TG, and ensure that it would also become applicable for NM testing as well as for general chemicals. 


\section{Sammanfattning och slutsatser}

Konferensen The Nordic NanoNet Workshop and EDC diskussion ordnades som en del av Finlands ordförandeskap för Nordiska ministerrådet (NMR) 2011. Konferensen ordnades av Säkerhets- och kemikalieverket (Tukes) i Finland och ägde rum 11-13 oktober 2011 på Hanaholmens kongresscenter i Esbo, Finland. Huvudtema för konferensen var säkerhetsbedömning och hantering av nanomaterial (NM). Dessutom ordnades parallellt en endagskonferens som tillägnades kriterier för endokrinstörande kemikalier (EDC). Organisatörerna är tacksamma för att Nordiska ministerrådet tillhandahöll resurser för mötet.

Konferensens huvudsakliga teman var följande:

- Regelverk och sambanden mellan NM och EDC

- Tillämpbarhet av riktlinjerna för testning och riskbedömningsmetodik för nanomaterial

- Möjligheter till regelverk för EDC och NM

- Regelverk om NM

- Utveckling av EDC-kriterier

- Framtida nordiskt samarbete kring regelverket

\section{Regelverk och sambanden mellan NM och EDC}

Jukka Ahtiainen (Tukes, FI) gav en inledande presentation av regelverket och sambanden mellan EDC och NM, och presenterade några av konferensens huvudteman och målsättningar. Henrik Tyle (Danish EPA, DK) talade i Pia Juul Nielsens ställe och använde Danish Endocrine Network som ett exempel på ett nätverk för lagstiftningsåtgärder som har förbättrat samförståndet mellan lagstiftare och vetenskapsmän. Petteri Talasniemi (Tukes, FI) presenterade OECD:s reviderade begreppsram (Conceptual Framework, CF) och poängterade att begränsningarna i vägledningen härrör från två källor: antingen är erfarenheten av användningen av ifrågavarande metod otillräcklig eller så tillför metoden inga betydande fördelar i förhållande till befintliga studier. Henrik Tyle förespråkade i sin presentation av OECD:s reviderade CF och utkast till vägledningsdokument (Guidance Document, GD) en fallspecifik utgångspunkt i bedömningen av kemikalier som beaktar all tillgänglig information. 
Emma Vikstad (Kemi, SE) betonade det överhängande behovet av en definition av nanomaterial som omfattar all "nanorelevant" lagstiftning inom EU. Poul Bo Larsen (Danish EPA, DK) poängterade att det krävs mycket arbete för att inkorporera nanomaterial i REACH och föreslog att separata och mer flexibla bestämmelser för nanomaterial parallellt med REACH eventuellt kunde vara en lämplig lösning.

Den första konferensdagen avslutades med diskussioner om regelverket och sambanden mellan EDC och NM i utbrytargrupper. Slutsatserna presenteras nedan.

\section{Gå vidare med beslut eller vänta på mer vetenskaplig information?}

Den ståndpunkt som fick mest understöd var att inte vänta på mer vetenskaplig information utan gå vidare med beslut och vägledning. Den höga osäkerheten kring och bristen på klarhet i hurdan information som behövs om nanoteknik förstärker viljan till snabba beslutsåtgärder. Inom EDC är grunden för bestämmelser och kunskapen bättre.

\section{Definitionen av nanomaterial}

Alla grupper ansåg att det finns ett överhängande behov av en definition av nanomaterial för att reglerande åtgärder ska vara möjliga. En praktisk strategi föredrogs i det rådande osäkra läget. Man enades emellertid om att den vetenskapliga grunden borde inkorporeras i denna praktiska strategi. Grupper var också överens om att det finns ett behov av en definition av EDC och kriterier som omfattar alla hormonstörningar.

\section{REACH - EDC, NM och lagstiftning}

Även om man inte uppnådde enighet i frågan om hur REACHförordningen skulle kunna garantera säkerheten hos NM, enades deltagarna om att ytterligare åtgärder för att garantera säkerheten behövs. Potentiella metoder för att garantera att NM behandlas separat från bulkmaterial inbegriper ändringar av lagstiftningen, nya reviderade tillägg eller adekvat vägledning från ECHA för registrering. Man ansåg att en ny bilaga om EDC-kriterier, som liknar den om PBT-kriterier, antagligen behövs för att identifiera EDC under REACH.

\section{Registrering av NM}

Den allmänna opinionen var att det vore säkrare att kategoriskt registrera NM som nya ämnen med nanoanpassade informationskrav. Andra lämpliga metoder, såsom bättre vägledning för registrering från ECHA, fick emellertid också understöd. 


\section{Den befintliga lagstiftningens tillräcklighet för reglering av EDC}

De befintliga verktygen ansågs i allmänhet tillräckliga för att reglera bekräftade EDC. De kombinerade följderna av EDC från olika källor ansågs emellertid vara svåra att behandla i tillräcklig grad enligt den gällande lagstiftningen.

\section{Tillämpbarhet av riktlinjerna för testning och riskbedömningsmetodik för nanomaterial}

Under den andra konferensdagen låg fokus på tillämpbarheten av riktlinjerna för testning (test guidelines, TG) och riskbedömningsmetoder (risk assesment, RA) för nanomaterial. Peter Kearns (OECD, EHS/ENV) gav en överblick av OECD:s arbete inom NM och uttalade sig närmare om förhållandet mellan principerna för god laboratoriesed och ömsesidigt godkännande av uppgifter i förhållande till riktlinjerna för testning och framtagningen av vägledningsdokument. Jukka Ahtiainen sammanfattade möjligheterna för vidareutveckling av testpraxisen: en möjlighet är att skapa en begreppsram för att testa och bedöma NM som liknar begreppsramen för EDC. Sjur Andersen (KLIF, NO) presenterade OECD:s sponsorprogram (Sponsorship Programme) samt förklarade testernas omfattning och introducerade de berörda sponsorerna. Janneck ScottFordsmand (DMU, DK) uttalade sig om det nordiska nanosilvrets bidrag till sponsorprogrammet och diskuterade några av utmaningarna vid testningen, vilket utlöste en het diskussion.

Erik Joner (Bioforsk, NO) och Deborah Oughton (Universitetet for miljø- og biovitenskap, NO) presenterade tillsammans studier om NM:s miljöeffekter: tester i relevanta jordtillstånd inklusive åldrande ansågs vara viktigt, såsom också möjligheterna att använda neutroner för att upptäcka NM i metall. Geert Cornelis (Göteborgs universitet, SE) inriktade sig på upptäckten av NM i miljön och frågor kring uppföljning av exponering - fältflödesfraktionering (FFF) kombinerat med induktivt kopplad plasma masspektrometri (ICP-MS) och single particle ICP-MS (SP-ICP-MS) föreslogs för känslig analys av syntetiska nanopartiklar i komplexa miljöer.

Marit Låg (Nasjonalt folkehelseinstitutt, NO) sammanfattade i sin presentation av inandning av nanopartiklar att syntetiska nanopartiklar har potential att förklara hälsoeffekter; toxiciteten beror på exponeringen för dessa partiklar. Julia Catalán (FIOH, FI) talade om testning av genotoxicitet i NM och dess utmaningar - man vet t.ex. sällan hur stor del av nanomaterialet som absorberas av cellerna och huruvida skillnader i intracellulära kanaler kan förklara skillnader i genotoxicitet. Lise Fjellsbø (NILU, 
NO) talade om in vitro-studier inom NM-testning och berättade om erfarenheter från projektet NanoTEST som analyserar hur nanopartiklar absorberas av och transporteras genom biologiska barriärer. I dagens sista presentation talade Jussi Kukkonen (Itä-Suomen yliopisto, FI) om effekterna i vattendrag och ödet för nanomaterial i nordisk miljö.

Diskussionen kring tillämpbarheten fortsatte i mindre grupper, diskussionernas slutsatser presenteras nedan.

\section{Befintliga riktlinjer för testning och ny vägledning}

Grupper enades om att utveckling av ytterligare riktlinjer är nödvändigt men de befintliga riktlinjerna är en bra utgångspunkt för säkerhets- och riskbedömningen av nanomaterial. Man erkände att det finns tekniska och begreppsmässiga utmaningar i de befintliga riktlinjerna. Alla grupper betonade behovet av flexibilitet i vägledningen.

\section{Vägledning för specifika testområden och vägledning som baserar sig på NM-grupper}

Olika vägledning för olika testområden ansågs nödvändigt. Det är fortfarande svårt att gruppera nanomaterial i praktiken. Man ansåg ändå att om dessa praktiska hinder i grupperingen kunde överkommas skulle det vara en bra grund för vägledningen.

\section{Möjligheter till regelverk för EDC och NM}

Konferensens tredje dag inleddes med ett möte om möjligheterna till regelverk för EDC och NM. Sofie Christiansen, Pia Juul Nielsen och Rikke Holmberg (Danish EPA, DK) presenterade resultatet från tre nordiska EDC-workshoppar angående kriterier, kombinerade påföljder och dispositiva regleringsåtgärder som ordnades i Köpenhamn hösten 2010. Rikke Holmberg informerade också om i vilket skede EU:s lagstiftningsarbete angående EDC, kombinerade effekter och NM befinner sig. Katarzyna Malkiewicz (Kemi, SE) avslutade mötet med en presentation av registreringen av zinkoxid i REACH och rekommenderade att begära ytterligare nanospecifika uppgifter $\mathrm{i}$ anslutning till materialutvärderingen i REACH. Representanter för danska EPA höll ett separat möte om utvecklingen av EDC-kriterier, parallellt med ett möte om regelverket kring nanomaterial. 


\section{Lagstiftning om NM}

Vid öppnandet av mötet om regelverket kring nanomaterial betonade Poul Bo Larsen (Danish EPA, DK) och Jukka Ahtiainen (Tukes, FI) uppkomsten av nya nanospecifika effektmått (endpoints) och behovet av att ta fram vägledning och nya riktlinjer för testning inom fysisk-kemiska egenskaper.

Henrik Laursen (DG ENV, EC) gav en överblick av EU:s viktigaste åtgärder och synpunkter på regelverket kring NM; syftet med den pågående överblicken av lagstiftningen är att fastställa huruvida den gällande lagstiftningen garanterar säkerhet och hållbarhet samt konkurrens och nytänkande. Marita Luotamo (ECHA) talade om erfarenheterna av NM och framtida utveckling under REACH: en fallspecifik strategi för registreringen av nanomaterial föredrogs.

Juan Piñeros (MoE, BE) tog upp harmonisering av nationella NMdatabaser på marknaden: till fördelarna hör möjligheten till insamling av data och uppskattning av exponering, riskbedömning och hanteringssystem samt förbättring av lagstiftningen. Clarisse Durand (Ministry of Ecology, Sustainable Development, Transport and Housing, FR) behandlade mer detaljerat initiativet till det obligatoriska franska rapporteringsschemat som inletts i samarbete med Belgien och Italien.

Nicole Palmen (RIVM, NL) presenterade exempel på säkerhetsbedömningen av NM, i synnerhet med tanke på exponering för syntetiska nanopartiklar i arbetet. Kaja Kasemets (NICPB, EE) stod för den sista presentationen och diskuterade forskningen kring ekotoxiciteten hos syntetiska nanopartiklar vid NICPB.

\section{Diskussion om nordiskt samarbete kring regelverket för NM}

Konferensen Nordic NanoNet Workshop avslutades med en diskussion kring det nordiska samarbetet inom EU och OECD. Slutsatserna av denna diskussion som är avsedda för lagstiftare presenteras nedan.

\section{OECD:s sponsorprogram och dess utveckling}

Förväntningarna på OECD:s testning av 13 nanomaterial för olika effektmått är mycket stora. Materialet från den pågående explorativa fasen 1 för identifiering av eventuella faror är ännu inte helt tillgängligt, men vi borde redan börja planera fas 2 , där data som uppkommer borde vara lämplig för riskbedömning. Testningen i fas 2 borde vägledas av en sorts teststrategi eller begreppsram, såsom för EDC, som utvecklas utifrån befintlig data. 


\section{Utveckling av TG och GD}

I princip kan OECD:s riktlinjer tillämpas på undersökning av hälsoeffekter, ecotoxicitet och miljöeffekter av nanomaterial men det är viktigt att även beakta det testade materialets fysikalisk-kemiska egenskaper. I vissa fall kan det finnas ett behov av ytterligare ändringar av OECD:s riktlinjer. Provberedningen och doseringen är ytterst viktiga i testerna och därför har man tagit fram ett vägledningsdokument för provberedning och dosimetri som tillämpas på säkerhetstestning av nanomaterial. Med tanke på den snabba utvecklingen i området har OECD-WPMN:s inledande utkast ansetts vara ett "levande" dokument som betonar olika metoders genomförbarhet och tillåter kontinuerliga uppdateringar.

Man enades om att väldigt få potentiella nya nanospecifika effektmått behöver läggas till riktlinjerna för testning eller tas fram som nya riktlinjer. Dessa nya nanospecifika behov berör främst området fysikaliskkemisk karakterisering. Vissa av effektmåtten i de befintliga riktlinjerna för testning är mer "nanorelevanta" än andra. Inom ekotoxicitet är de flesta befintliga effektmåtten också "nanorelevanta". Inom miljöeffekter utgörs utmaningen i testningen av identifiering och karakterisering av NM i miljö eller vävnad.

\section{Implementering av REACH}

Informationen i registreringsunderlaget för ett nanomaterial, som en del av bulkregistrering eller individuellt, måste överensstämma med informationskraven och vid behov med CSR-kraven för registrantens alla identifierade användningssyften för nanomaterial.

Det finns ingen lösning av typen one-size-fits-all i behandlingen av nanomaterial som bulksubstans eller en separat substans. Vidare testning måste fokusera på att ta fram regler för hur storleken ska användas som ett särdrag och när den ska användas som en identifierare. De nordiska länderna har eventuellt skilda åsikter om huruvida NM alltid ska registreras som separata substanser och behandlas som nya substanser. Om det senare skulle gälla borde informationskrav styrda av tonnage eventuellt tänkas över igen.

Om specifika regler för identifiering av nanomaterialets substans utvecklas måste de överensstämma med den allmänna praxisen för substanser. Sådana regler måste ha en viss flexibilitet för att tillåta tillämpning av de mest praktiska lösningarna, förutsett att informationen är relevant och fullständig för alla former av substansen och att säker användning garanterats.

REACH kräver att registranten säkerställer att hans registrering(ar) visar att alla former av substansen i underlaget kan användas på ett säkert sätt. Substansens identitet är inte viktig i detta avseende. Fokus 
borde därför riktas mot att säkerställa att uppgifterna kan tillämpas och gäller för alla former i underlaget i fråga, samt att säkerställa att registranten har lämnat all relevant information för att nedströmsanvändare och konsumenter kan använda substansen på ett säkert sätt. Det finns emellertid oro bland de nordiska länderna om huruvida industrin följer detta på rätt sätt. Endast 3 av 46 registranter som använt NM med samma substanser hade meddelat om användningen av nanomaterial $i$ IUCLID i samband med den första registreringen 2010.

Standardkraven på information, såsom förklaras i bilagorna VII-XI, gäller lika för nanoformer och bulkformer. Om tester utförs måste registranten säkerställa att testerna representerar den registrerade substansens form(er). Man sammanfattade att kraven på nanospecifik data skulle behöva nya "tonnage triggers" och datakrav. Detta skulle också medföra ett behov av gemensam registrering.

ECHA har bjudits in till att vidareutvärdera underlagen i en bottomup-process för att få mer kunskap om och erfarenhet av att identifiera substanser vid registreringen av nanomaterial. I tillämpliga fall borde ECHA använda denna erfarenhet till att ta fram ytterligare praktiskta regler i samarbete med Euroepiska kommissionen, medlemsstaterna och intressenter. En dylik bottom-up-process torde bidra betydligt till en bättre förståelse av hur nanomaterial ska behandlas inom REACHramen. De nordiska länderna stöder eventuellt detta som en tillfällig lösning. ECHA:s reviderade vägledningsdokument om registrering borde emellertid klargöra att registranterna och SIEF ska föra fram och bedöma all relevant användning av NM i substansen i fråga. Detta krav ska vara mycket tydligt och klart, förslagsvis under rubriken "Vad ska registreras."

Man föreslog också att om en medlemsstats lagstiftare oroar sig för att säkerhetsbedömningen av en NM-form är otillräcklig ska dessa substanser (t.ex. fallet $\mathrm{ZnO}$ som har en nanoform på marknaden) kunna föras till CORAP-processen av en medlemsstat.

Man diskuterade också huruvida ett separat regelverk för nanomaterial skulle vara mer lämpligt för att undvika ändringar inom REACH. På basis av erfarenheterna från RIP-oNs och OECD:s sponsorprogram kunde ett framtida nordiskt samarbete bestå av att studera specifika triggers för datakrav och en teststrategi för nanomaterial. 


\section{Skapande av ett nordiskt regelverk för NM}

Att stärka det nordiska samarbetet inom nanosäkerhet understöddes. Detta torde föra samman forskningsgrupper och lagstiftare. Synpunkter om lagstiftningen kan på så sätt diskuteras och koordineras bättre. Kärnan i denna nanogrupp skulle alltså koordinera arbete i anslutning till NM i alla NKG-grupper.

Om de nordiska länderna har orsak att tvivla på tillräckligheten av säkerhetsbedömningen av NM vid registreringen, och ett av länderna för ärendet till CORAP-processen för utvärdering av substansen ska de nordiska länderna stötta processen och bidra med resurser.

Inledandet av ett TG/GD-projekt i OECD:s program för riktlinjer för testning diskuterades som en konkret idé för framtida samarbete inom lagstiftning. Under mötet identifierades två möjliga områden där det finns behov av arbete och nordisk vetenskap. Inom ekotoxikologi är framtagningen av vägledningsdokument för toxicitet $\mathrm{i}$ jord och sediment ett sådant område. Vad gäller människans hälsa kunde kunskap inom bedömningen av genotoxicitet identifieras tydligt. En möjlighet är att engagera sig i utvecklingen av en "Comet assay" för en OECD TG och säkerställa att den också kan tillämpas på NM-testning så väl som på allmänna kemikalier. 


\section{Abbreviations}

\begin{tabular}{|c|c|}
\hline ADME & Adsoptrion Distribution Metabolism and Excretion \\
\hline ALARA & As-low-as-reasonably-achievable \\
\hline ATP & Admendment to Technical Process (REACH \& CLP) \\
\hline BAL & Bronchious alveoli lavage \\
\hline BfR & Federal Institute for Risk Assessment (Germany) \\
\hline CARACAL & Competent Authorities for REACH and CLP \\
\hline CASGnano & CARACAL sub-group on nanomaterials \\
\hline cFFF & Centrifucal Field Flow Fractionation \\
\hline CLP & Classification, Labelling and Packaging \\
\hline CMR & Carcinogenic, Mutagenic or Toxic to Reproduction (Hazard classification) \\
\hline COPD & Chronic Obstructive Pulmonary Disease \\
\hline CORAP & Community Rolling Action Plan (REACH) \\
\hline CSR & Chemical Safety Report (REACH) \\
\hline DIT & Developmental Immutoxicity \\
\hline DNEL & Derived No-Effect Level \\
\hline DNT & Developmental Neurotoxicity \\
\hline ED & Endocrine Disruptor or Endocrine Disruption \\
\hline EDC & Endocrine Disrupting Chemical \\
\hline EDTA AG & Endocrine Disrupters Testing and Assessment Advisory Group \\
\hline EHS & Environmental Health and Safety \\
\hline ENP & Engineered nanoparticle \\
\hline ENV & Environmental \\
\hline EOGRTS & Extended One Generation Reproduction Toxicity Study \\
\hline ERA & Environmental Risk Assessment \\
\hline EU MS & EU Member State \\
\hline EU TM & EU Test Method \\
\hline FFF & Field Flow Fractionation \\
\hline FFLCT & Fish Full Life-cycle Test \\
\hline FSA & Fish Screening Assay \\
\hline FSDT & Fish Sexual Development Test \\
\hline FSTRA & Fish Short-Term Reproduction Assay \\
\hline GHS & Globally Harmonized System for Classicication and Labelling \\
\hline GLP & Good Laboratory Practise (OECD) \\
\hline GNSPD & Guidance Notes for Sample Preparation and Dosimetry (OECD) \\
\hline HARN & High Aspect Ratio Nanomaterial \\
\hline HPVC & High Production Volume Chemicals \\
\hline ICP-MS & Inductively Coupled Plasma-Mass Spectrometry \\
\hline IPCS & International Programme on Chemical Safety \\
\hline IUCLID & International Uniform Chemical Information Database \\
\hline MAD & Mutual Acceptance of Data (OECD) \\
\hline MMGT & Medaka Multigeneration test \\
\hline MS & Member State \\
\hline MSC & Member State Committee (ECHA) \\
\hline MW & Molecular Weight \\
\hline NGO & Non-Governmental Organisation \\
\hline NM & Nanomaterial \\
\hline NOAEL & No Observed Adverse Effect Level \\
\hline NOEC & No Observed Effect Concentration, Lowest Observed Effect Concentration \\
\hline NOEL & No Observed Effect Level, Lowest Observed Effect Level \\
\hline nZVI & nano-Zero Valent Iron \\
\hline OECD CF & OECD Conceptual Framwork for endocrine disrupters testing \\
\hline OECD GD & OECD Guidance Document \\
\hline OECD GD 140 & Androgenized Stickleback Screening assay \\
\hline OECD TG & OECD Test Guideline \\
\hline OECD WPMN & OECD Working Party on Manufactured Nanomaterials \\
\hline
\end{tabular}




\begin{tabular}{|c|c|}
\hline OECD TG 206 & Avian Reproduction Test \\
\hline OECD TG 211 & Daphnia magna Reproduction Test \\
\hline OECD TG 218, 219 & Chrironomid Reproduction Test \\
\hline OECD TG 222 & Earthworm reproduction test \\
\hline OECD TG 225 & Lembriculus sediment worm toxicity test \\
\hline OECD TG 229 & Fish Short Term Fish Screening Assay \\
\hline OECD TG 230 & 21-day Fish Assay \\
\hline OECD TG 231 & Amphibian Metamorphosis Assay \\
\hline OECD TG234 & Fish Sexual Development Test \\
\hline OECD TG 407 & Repeated Dose 28-day Oral Toxicity Study in Rodents \\
\hline OECD TG 415 & One-Generation Reproduction Toxicity Study \\
\hline OECD TG 416 & Two-Generation Reproduction Toxicity \\
\hline OECD TG 440 & Uterotrophic assay \\
\hline OECD TG 441 & Herschberger assay \\
\hline OECD TG 443 & Extended on generation reproductive toxicity study (EORGTS) \\
\hline OEL & Occupational exposure Limit \\
\hline PBT & Persistent, Bioaccumulative and Toxic \\
\hline PM & Particulate Matter \\
\hline PNEC & Predicted No-Effect Concentration \\
\hline P-NRV & Provisional nanoreference value \\
\hline PPP & Plant Protection Product \\
\hline PVA & Poly vinyl acetate \\
\hline QSAR & Quantitative Structure Activity Relationship \\
\hline RA & Risk Assessment \\
\hline REACH & Regulation (EC) no 1907/2006 on Registration, Authorisation and Restriction of Chemicals \\
\hline RIPoN & REACH Implementation Project on nanomaterials \\
\hline ROS & Reactive Oxygen Species \\
\hline SCENIHR & Scientific Committee for Emerging and Newly Identified Health and Environmental Risks \\
\hline SEM & Scanning Electron Microscope \\
\hline SNUR & Significant New Use Rule (USEPA) \\
\hline SP-ICP-MS & Single Particle Inductively Coupled Plasma- Mass Spectrometry \\
\hline STOT & Specific Target Organ Toxicant \\
\hline TEM & Transmission Electron Microscope \\
\hline TGD & Technical Guidance Document \\
\hline TRISK & European Toxicology Risk Assessment Training \\
\hline WoE & Weight of Evidence \\
\hline
\end{tabular}




\section{Appendix A: Programme}

Nordic NanoNet Workshop for researchers and regulators on safety evaluation of nanomaterials and Nordic discussion on EDC criteria

\section{Hanasaari Congress Centre, Espoo, Finland}

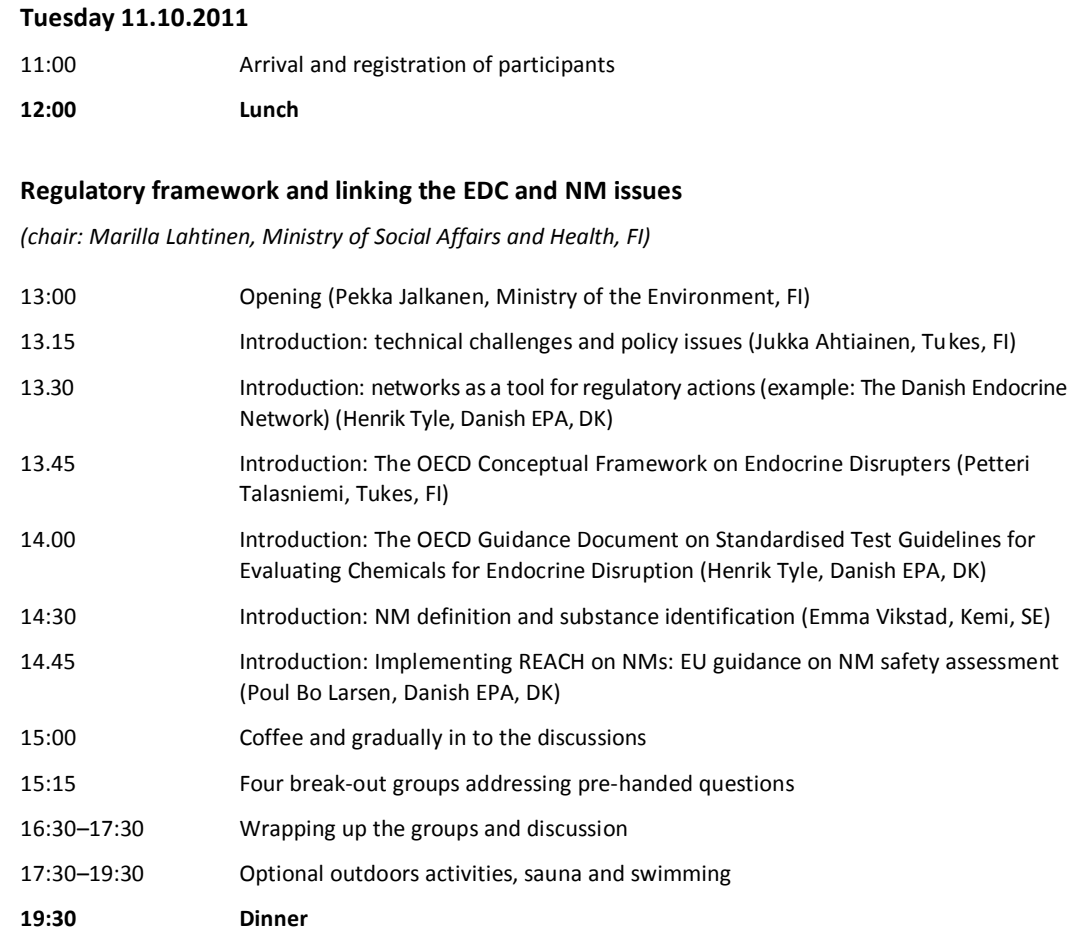




\section{Wednesday 12.10.2011}

\section{Test guidelines and their applicability to assess NMs}

(chair: Ivar Lundbergh, Kemi, SE)

\begin{tabular}{|c|c|}
\hline 9:00 & $\begin{array}{l}\text { What TG tools we have, and which TGs and GDs have to be developed for NM testing } \\
\text { (Peter Kearns, OECD EHS/ENV) }\end{array}$ \\
\hline 9:30 & $\begin{array}{l}\text { Addressing the data requirements for the safety assessment of NMs under REACH (Juan } \\
\text { Riego Sintes, JRC Ispra, EC) }\end{array}$ \\
\hline 10.00 & OECD Sponsorship Programme and NM testing (Sjur Andersen, KLIF, NO) \\
\hline 10:15 & $\begin{array}{l}\text { Nordic nanoAg contribution to the Sponsorship Programme (Janneck Scott-Fordsmand, } \\
\text { DMU, DK) }\end{array}$ \\
\hline $10: 45$ & $\begin{array}{l}\text { Environmental fate studies on NMs (Erik Joner, Bioforsk, NO and Deborah Oughton, } \\
\text { Norwegian University of Life Sciences, NO) }\end{array}$ \\
\hline 11.15 & Coffee \\
\hline $11: 45$ & $\begin{array}{l}\text { Detection of NMs in the environment and verification of exposure (Geert Cornelis, } \\
\text { University of Gothenburg, SE) }\end{array}$ \\
\hline $12: 15$ & $\begin{array}{l}\text { Inhalation of nanoparticles and health effects (Marit Låg, Norwegian Institute of Public } \\
\text { Health, NO) }\end{array}$ \\
\hline $12: 45$ & Discussion \\
\hline 13:00 & Lunch \\
\hline \multicolumn{2}{|c|}{ (chair: Yvonne Andersson, Kemi, SE) } \\
\hline 14.00 & Update on genotoxicity of NMs (Julia Catalán, FIOH, FI) \\
\hline $14: 30$ & In vitro studies in NM testing - Experience from NanoTEST (Lise Fjellsbø, NILU, NO) \\
\hline $15: 00$ & $\begin{array}{l}\text { Aquatic effects and fate of nanomaterials in the Nordic environment (Jussi Kukkonen, } \\
\text { University of Eastern Finland, FI) }\end{array}$ \\
\hline \multirow[t]{3}{*}{ 15:30 } & Coffee and break-out groups (4) on applicability of TGs and testing \\
\hline & 2 ecotox (moderators, rapporteurs) \\
\hline & 2 tox (moderators, rapporteurs) \\
\hline $16: 30$ & Wrapping up and discussion \\
\hline $17: 00$ & End of the day \\
\hline 17:00-19:30 & Optional outdoors activities, sauna and swimming \\
\hline 19.30 & Dinner \\
\hline
\end{tabular}




\section{Thursday 13.10.2011}

\section{A common session on linking the EDC and NM issues followed by two parallel sessions for}

nanomaterial testing and assessment and for EDC criteria

\section{Common session}

(chair: Henrik Tyle, Danish EPA, DK)

Outcome of the three Nordic workshops on EDCs held in Denmark in the autumn 2010 (Combined effects, Criteria and Soft Regulatory Measures) (Sofie Christiansen DTU and Pia Juul Nielsen, Danish EPA, DK)

8.45 Regulation of combined effects - status of the EU work (Rikke Holmberg, Danish EPA, DK)

9.15 Registration of $\mathrm{ZnO}$ in REACH - is it sufficient for safety evaluation of nano $\mathrm{ZnO}$

(Katarzyna Malkiewicz, Kemi, SE)

\section{Session on EDC criteria}

(chair: Pia Juul Nielsen, Danish EPA, DK)

10.00-10.30 Establishment of the Danish proposal for criteria and options for regulation of endocrine disruptors under REACH (Pia Juul Nielsen, Danish EPA)

\subsection{0-10.45 Coffee break}

10.45-11.15 Revised OECD conceptual framework for endocrine disruptors and introduction to the OECD Guidance Document on Standardised Test Guidelines for Evaluating Chemicals for Endocrine Disruption (Henrik Tyle, Danish EPA (ENV) and Sofie Christiansen (HH), Division of Toxicology and Risk Assessment, National Food Institute, Technical University of Denmark)

11.15-12.00 Science based criteria for endocrine disruptors developed by the Danish centre on Endocrine Disrupters (Sofie Christiansen, Division of Toxicology and Risk Assessment, National Food Institute, Technical University of Denmark and Henrik Holbech, Institute of Biology, University of Southern Denmark)

12.00-13.00 Lunch

13.00-13.30 Criteria for endocrine disrupters - central discussion points (Marie Louise Holmer Danish EPA)

13.30-15.00 Break out discussions in small groups of approximately 6 participants per group (questions for discussion will be handed out in the beginning of the day)

15.00-15.45 Reports from the break out groups and short overview of the outcome of the day

15:45 Discussion and conclusions

16:00 End of the workshop

Session on regulating NMs

9:30 Summary on the TG applicability and TG/GD needs (Poul Bo Larsen, Danish EPA, DK and Jukka Ahtiainen, Tukes, FI)

10:00 Current regulatory (REACH) views in EU (Henrik Laursen, DG ENV, EC)

10:30 Registrations of NMs (Marita Luotamo, ECHA)

11:00 Coffee

11.30 NMs in products: labelling and product registers (Juan Pineros, MoE, BE / Clariss Durand, Ministry of Ecology, sustainable Development, Transports and Housing, FR)

12:00 Example(s) on NM safety assessment and RMM (Nicole Palmen, RIVM, NL)

12:30 Nanotoxicology: Science at the interphases, Estonian perspective (Kaja Kasemets, National Institute of Chemical Physics and Biophysics, EE

13.00

Lunch and room check-out 
(chair: Flemming Ingerslev, Danish EPA, DK)

Can we build common views on the OECD and EU work? Discussion lead by the chair and a panel on the issues OECD Sponsorship Programme and its progress

TG and GD development

REACH implementation (substance ID, data requirements, risk assessment and risk management)

NM product labelling and registers 


\section{Appendix B: Presentations}

PowerPoint slides for selected Nordic NanoNet Workshop presentations, made available by their authors, can be accessed at the following address: http://www.tukes.fi/nanoturvallisuus 



\section{Appendix C: List of Participants}

\section{Denmark}

Anna-Maria Andersson Poul Bo Larsen

Berit Hallam

Rikke Holmberg

Marie Louise Holmer

Flemming Ingerslev

Pia Juul Nielsen

Henrik Tyle

Henrik Holbech

Janneck Scott-Fordsman

Sofie Christiansen
Centre on Endocrine Disrupters, Copenhagen University Hospital

Danish Environmental Protection Agency (MST)

Danish Environmental Protection Agency (MST)

Danish Environmental Protection Agency (MST)

Danish Environmental Protection Agency (MST)

Danish Environmental Protection Agency (MST)

Danish Environmental Protection Agency (MST)

Danish Environmental Protection Agency (MST)

Institute of Biology, University of Southern Denmark (SDU)

National Environmental Research Centre (DMU), Aarhuus University

National Food Institute, Technical University of Denmark (DTU)

\section{Finland}

\begin{tabular}{ll}
\hline Markus Sillanpää & Finnish Environment Institute (SYKE) \\
Helena Valve & Finnish Environment Institute (SYKE) \\
Anja Hallikainen & Finnish Food Safety Authority (Evira) \\
Julia Catalan & Finnish Institute of Occupational Health (TTL) \\
Sirpa Huuskonen & Finnish Institute of Occupational Health (TTL) \\
Helene Stockmann-Juvala & Finnish Institute of Occupational Health (TTL) \\
Virpi Väänänen & Finnish Institute of Occupational Health (TTL) \\
Jukka Ahtiainen & Finnish Safety and Chemicals Agency (Tukes) \\
Annette Ekman & Finnish Safety and Chemicals Agency (Tukes) \\
Elina Ekokoski & Finnish Safety and Chemicals Agency (Tukes) \\
Päivi Karnani & Finnish Safety and Chemicals Agency (Tukes) \\
Susan Londesborough & Finnish Safety and Chemicals Agency (Tukes) \\
Selma Mahiout & Finnish Safety and Chemicals Agency (Tukes) \\
Leona Mattsoff & Finnish Safety and Chemicals Agency (Tukes) \\
Kirsi Myöhänen & Finnish Safety and Chemicals Agency (Tukes) \\
Hinni Papponen & Finnish Safety and Chemicals Agency (Tukes) \\
Jaana Pasanen & Finnish Safety and Chemicals Agency (Tukes) \\
Petteri Taalasniemi & Finnish Safety and Chemicals Agency (Tukes) \\
Elina Väänänen & Finnish Safety and Chemicals Agency (Tukes) \\
Pirjo Tuomi & Golder Associates Oy \\
Leena Mannonen & Ministry of Agriculture and the Forestry (MMM) \\
Leila Vilhunen & Ministry of Employment and the Economy (TEM) \\
Pekka Jalkanen & Ministry of the Environment (YM) \\
Marilla Lahtinen & Ministry of Social Affairs and Health (STM) \\
Matti Viluksela & National Institute for Health and Welfare (THL) \\
Katri Talvioja & Orion Pharma \\
Maarit Priha & Pöyry Finland Oy \\
Ulrika Backman & Technical Research Centre of Finland (VTT) \\
Markus Linder & Technical Research Centre of Finland (VTT) \\
Nina Nieminen & Technology Centre KETEK Ltd \\
Jussi Kukkonen & University of Eastern Finland (ISY) \\
Nina Honkela & University of Helsinki \\
Arho Toikka & University of Helsinki \\
Annika Adamsson & University of Turku \\
\hline &
\end{tabular}




\section{Island}

Sigurbjörg Gísladóttir

Environment Agency of Iceland (UST)

\section{Norway}

Sjur Andersen

Marius Gudbransen

Erik Jone

Lise Marie Fjellsb $\varnothing$

Marit Låg

Ailbhe Macken

Deborah Oughton
Climate and Pollution Agency (KLIF)

Climate and Pollution Agency (KLIF)

Norwegian Institute for Agricultural and Environmental Research (Bioforsk)

Norwegian Institute for Air Research (NILU)

Norwegian Institute of Public Health (FHI)

Norwegian Institute for Water Research, Ecotoxicology and Risk Assessment (NIVA)

Norwegian University of Life Sciences (UMB)

\section{Sweden}

$\begin{array}{ll}\text { Kettil Svensson } & \text { National Food Agency (SLV) } \\ \text { Alicja Andersson } & \text { Swedish Chemicals Agency (Kemi) } \\ \text { Yvonne Andersson } & \text { Swedish Chemicals Agency (Kemi) } \\ \text { Åsa Bringmyr } & \text { Swedish Chemicals Agency (Kemi) } \\ \text { Celia Fischer } & \text { Swedish Chemicals Agency (Kemi) } \\ \text { Edda Hahlbeck } & \text { Swedish Chemicals Agency (Kemi) } \\ \text { Lena Hellmér } & \text { Swedish Chemicals Agency (Kemi) } \\ \text { Ivar Lundbergh } & \text { Swedish Chemicals Agency (Kemi) } \\ \text { Katarzyna Malkiewiz } & \text { Swedish Chemicals Agency (Kemi) } \\ \text { Ing-Marie Olsson } & \text { Swedish Chemicals Agency (Kemi) } \\ \text { Brita Oredsson Hagström } & \text { Swedish Chemicals Agency (Kemi) } \\ \text { Emma Vikstad } & \text { Swedish Chemicals Agency (Kemi) } \\ \text { Maria Wallén } & \text { Swedish Chemicals Agency (Kemi) } \\ \text { Geert Cornelis } & \text { University of Gothenburg }\end{array}$

Other

Clarisse Durand (by teleconference) Ministry of Ecology, Sustainable Development, Transports and Housing, France Henrik Laursen

Marita Luotamo DG Environment, European Commission (EC)

Peter Kearns

European Chemicals Agency (ECHA)

Juan Piñeros Garcet

Environment, Health and Safety Programme, OECD (OECD EHS/ENV)

Kaja Kasemets

Federal public service for health, food chain safety and the environment, Belgium

National Institute of Chemical Physics and Biophysics (KBFI), Estonia

Nicole Palmen

National Institute for Public Health and the Environment (RIVM), The Netherlands 
Nordic Council of Ministers

Ved Stranden 18

DK-1061 København K

www.norden.org

\section{Regulatory Safety Assessment of Nanomaterials}

The Nordic NanoNet Workshop and EDC discussion was organised in October 2011 in Espoo, Finland as part of the 2011 Finnish chairmanship of the Nordic Council of Ministers (NMR). The workshop focused on the safety assessment and management of nanomaterials (NMs) while reflecting on experiences in regulating endocrine disrupting chemicals (EDCs). This report describes the presentations, break-out group discussions and conclusions of the meeting. The regulatory frameworks and links between NMs and EDCs as well as the applicability of test guidelines and risk assessment tools for nanomaterials were addressed in presentations and break-out group work. Regulatory possibilities were further considered in a panel-led discussion. The Nordic dimension was of special interest: strengthening of Nordic regulatory cooperation in the field of nanosafety gained support, while commencing a TG/GD project in the OECD test guideline programme was seen a concrete idea for future cooperation. 